\title{
骨盤骨折を伴う後部尿道損傷
}

\author{
名古屋市立大学医学部泌尿器科学教室
} (主任：岡 直友教授）

杉浦

浦

\section{OBSERVATIONS ON URETHRAL INJURY ASSOCIATED WITH PELVIC FRACTURE}

\author{
by
}

Hajime Sugiura

From the Department of Urology, Nagoya City Universiy Metdical School

(Director: Prof. N. Oka)

Statistical studies and analysis of the cases of urethral injuries associated with pelvic fracture collected from 38 departments of urology of medical school in Japan were performed.

The data were compared with those of our hospital. References to the orthopedic data of our hospital were made, too.

Some case reports warning enough against the time-missing treatment were also made.

From the results above, early accurate diagnosis and deliberate first aid for this kind of patients were emphasized, which lead to the good prognosis.

\section{緒言}

経済の高度成長に伴い土木建築や交通機関，とくにこ $こ 2 \sim 3$ 年間に打社る自動車利用の目ざましい発達につ れ，これらの事故による外傷性疾患が激増し“交通戦 争”ともいわれるぐらい大きな社会問題となつている.

今回, 著者は金沢にて開催された日本泌尿器科学会第 18回中部連合地方会（昭和42年11月 3 日）に扣ける黒田 恭一教授司会のシンポジウム, 「泌尿器外傷」の席で “骨盤骨析を伴う後部尿道損傷”についての概要を発表 させて戴いたからここに改めてその詳細を記す。

さて尿道損傷は尿性器系の外傷中最も専門的な処置を 必要とするが, 骨盤骨折を伴う場合には泌尿器科のみな らず整形外科領域との関係も重要であろう。この場合, 外傷に対する一般的な処置（例えばショック，出血等に 対するもの）が先決問題であることは論をまたないが， 現実において，骨盤骨折を伴う後部尿道損傷に対しては いかなる時にいかなる処置を施行しているのか，その実 態を知るため全国大学関係病院へのアンケートの御返事 からの集計, 自験例, 特よび本学整形外科学教室で取扱 つた本症の 3 方面から研究した点を述べる.

\section{I. アンケートよりの集計}

アンケートの調査項目は，1964年から 1966年までの

* 助教授
過去 3 年間に打ける本症について, 例数, 性, 年令, 主 訴, 受傷原因, 受傷後泌尿器科受診までの時間的経過, 自覚症状 (ショック状態の有無, 外尿道口よりの出血ま たは血尿, 排尿障害の有無, 下腹部・会陰部の疼痛・腫 脹の有無), 他覚的症状 (直腸診に括ける前立腺触診の可 否, 尿道撮影飞拈ける造影剤の尿道外溢流現象の有無, 骨折部位および程度，ネラトンまたはブジー挿入の可 否, 尿浸潤の有無, 感染の有無), 尿道損傷の程度 (志田 分類 ${ }^{15)}$ ), 診断, 治療方法 (外科的処置ならびに術式, 留 置カテーテル法), 治癒所要日数, 経過・予後, 合併症拈 よび後遺症についてである.

な敃御返事を扮寄せ下さつた下記大学に深甚の謝意を 表します。

北大, 札医大, 弘大, 岩手医大, 東北大, 福島医大, 千大, 東大, 東大分院, 東医歯大, 東邦大, 日大, 日大 分院, 東医大, 昭和大, 順大, 横市大, 新大, 信大, 金 大, 岐大, 名大, 三重大, 京大, 阪大, 阪市大, 阪医 大, 神大, 和医大, 鳥取大, 広島大, 山口大, 德大, 九 大, 長大, 熊大, 鹿大.

以上, 解答を寄せて頂いた 37 機関と名市大の症例（計 38機関）から集計研究した点について述べる.

1. 総数

1）例数㧊よび頻度 
第 1 表 フンケートの集計例数

46 大学, 3 分院・計 49 機関 $1964-1966: 3$ 年間

\begin{tabular}{|c|c|c|c|}
\hline & 機関名 & 例 数 & $\begin{array}{l}\text { 泌尿器外 } \\
\text { 傷中 } \%\end{array}$ \\
\hline 1 & 北 大 & 0 & \\
\hline 2 & 札 医大 & 3 & 10.0 \\
\hline 3 & 弘 大 & 2 & 22.2 \\
\hline 4 & 岩手医大 & 4 & 20.0 \\
\hline 5 & 東 北大 & 7 & 35.0 \\
\hline 6 & 福島医大 & 0 & \\
\hline 7 & 千 大 & 1 & 5.9 \\
\hline 8 & 東大 & 1 & 12.5 \\
\hline 9 & 東大分院 & 0 & \\
\hline 10 & 東医畨大 & 2 & 20.0 \\
\hline 11 & 東 邦 大 & 3 & 13.3 \\
\hline 12 & 日 大 & 7 & 0.5 \\
\hline 13 & 日大分院 & 6 & 50.0 \\
\hline 14 & 東医大 & 7 & \\
\hline 15 & 昭 医 大 & 1 & \\
\hline 16 & 順 大 & 0 & \\
\hline 17 & 横 市大 & 7 & 18.0 \\
\hline 18 & 新 大 & 8 & 33.3 \\
\hline 19 & 信 大 & 6 & 40.0 \\
\hline 20 & 金 大 & 6 & 15.0 \\
\hline 21 & 岐 大 & 7 & 18.6 \\
\hline 22 & 名 大 & 0 & \\
\hline 23 & 名市大 & 5 & 17.9 \\
\hline 24 & 三重大 & 10 & \\
\hline 25 & 京 大 & 6 & 66.6 \\
\hline 26 & 阪 大 & 4 & 17.4 \\
\hline 27 & 大阪市大 & 0 & \\
\hline 28 & 大阪医大 & 0 & \\
\hline 29 & 大 & 15 & 34.1 \\
\hline 30 & 和 医 大 & 7 & \\
\hline 31 & 鳥取大 & 0 & \\
\hline 32 & 広大 & 5 & 35.7 \\
\hline 33 & 山口大 & 3 & 3.3 \\
\hline 34 & 徳 大 & 8 & \\
\hline 35 & 九 大 & 6 & 25.0 \\
\hline 36 & 長 大 & 2 & 3.3 \\
\hline 37 & 熊 大 & 1 & 16.7 \\
\hline 38 & 鹿 大 & 0 & \\
\hline 計 & 38 機 関 & 150例 & 22.2 \\
\hline
\end{tabular}

回収率 : $38 / 49=77.6 \%$

全国46大学, 3 分院計 49 機関中解答の得られたのは第 1 表に示寸38機関，回收率 $78 \%$ で，例数は 150 例，泌尿
第 2 表 地方別症例数

\begin{tabular}{|c|c|c|c|c|}
\hline 連合地方会名 & 機関数 & 例数 & 機関 & 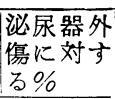 \\
\hline 東部連合地方会 & 19 & 65 & 3.4 & 21.6 \\
\hline 中部連合地方会 & 11 & 60 & 5.5 & 28.3 \\
\hline 西部連合地方会 & 8 & 25 & 3.1 & 16.8 \\
\hline 計 & 38 & 150 & 4.0 & 22.2 \\
\hline
\end{tabular}

第 3 表 年令扣よび性別

\begin{tabular}{|c|c|c|c|c|}
\hline 年 令 & 男 子 & 女子 & 計 & $\%$ \\
\hline 1〜 6才 & 6 & 1 & 7 & 4 \\
\hline $7 \sim 12$ & 9 & 1 & 10 & 7 \\
\hline $13 \sim 20$ & 18 & & 18 & 12 \\
\hline $21 \sim 30$ & 35 & 2 & 37 & 25 \\
\hline $31 \sim 40$ & 44 & & 44 & 29 \\
\hline $41 \sim 50$ & 10 & & 10 & 7 \\
\hline $51 \sim 60$ & 14 & & 14 & 9 \\
\hline 61 才以上 & 10 & & 10 & 7 \\
\hline 計 & 146 & 4 & 150 & \\
\hline$\%$ & 97 & 3 & & 100 \\
\hline
\end{tabular}

器外傷中本症の占める頻度は平均 $22 \%$ であつた。

2) 地方別症例数

第 2 表は便宜上連合地方会別に分類した表であるが中 部地区 (中部, 北陸, 近畿地方) が 1 機関当 り 5.5 例 と最も高い值を示した. 東部 (北海道, 東北, 関東, 甲 信越地方）拉よび西部地区（山陰，山陽，四国，九州地 方）ではそれぞれ 3.4，3.1例であつた。 な特 1 機関当 りの平均は 4.0 例となつている. また泌尿器外傷に対す る本症の百分率も中部地区が最も高く $28 \%$ となつてい る.

\section{3）年令执よび性別}

第 3 表は年:令および性別と尿道外傷の頻度との関係を 示すが，150例中男子は 146例（97\%）と圧倒的に多 く，年令別では㗢き盛りの青壮年期すなわち20４0才代 に集中し， 150 例中 81 例 $(54 \%)$ で全体の半数を占めて いる.

4）受傷原因と年令

第 4 表は受傷原因と年令との関係を示したものである が，各年令層ともに交通事故によるものが多く 150例中 95例（男子91例，女子 4 例), $63 \%$ を占めている。

5）泌尿器科受診までの時間 
第 4 表 受傷原因と年令（性）との関係

\begin{tabular}{|c|c|c|c|c|c|c|}
\hline 年 令 & $\begin{array}{c}\text { 交通 } \\
\text { 事故 }\end{array}$ & $\begin{array}{c}\text { 腰部 } \\
\text { 迫 }\end{array}$ & 転落 & その他 & 計 & $\%$ \\
\hline $1 \sim 6$ 才 & $6(1)$ & 0 & 0 & 0 & 7 & 4 \\
\hline $7 \sim 12$ & $7(1)$ & 0 & 1 & 1 & 10 & 7 \\
\hline $13 \sim 20$ & 13 & 3 & 0 & 2 & 18 & 12 \\
\hline $21 \sim 30$ & $22(2)$ & 5 & 3 & 5 & 37 & 25 \\
\hline $31 \sim 40$ & 25 & 9 & 3 & 7 & 44 & 29 \\
\hline $41 \sim 50$ & 3 & 2 & 2 & 3 & 10 & 7 \\
\hline $51 \sim 60$ & 8 & 3 & 3 & 0 & 14 & 9 \\
\hline 61 才上 & 7 & 1 & 1 & 1 & 10 & 7 \\
\hline 計 & $91(4)$ & 23 & 13 & 19 & 150 & \\
\hline \% & 63 & 15 & 9 & 13 & & 100 \\
\hline
\end{tabular}

第 1 図. 泌尿器科受診迄の時間

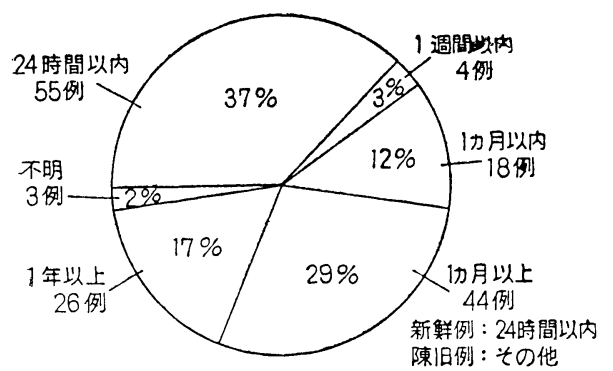

本症の多くは受傷状況, 受傷部位の関係から直接, 大 学附属病院の泌尿器科を訪れることは少いといわれてい るが，アンケートから得られた解答によると第 1 図のご とく24時間以内に受診している例が全体の約 1 / すなわち 150例中55例 $(37 \%)$ を占めている.

以下，多少戦密なきらいはあるが24時間以内に受診し たものを新鮮例, それ以外を陳旧例として比較検討し た。

すなわち 150 例中, 新鮮例は 55 例 $(37 \%)$ らち女子 2 例 $(3.6 \%)$,陳旧例は95例 $(63 \%)$ となつている.

2. 新鮮例おょよ゙陳旧例

1) 主訴

第 2 図は新鮮例と陳旧例の主訴を図示したものであ るが，新鮮例では尿道出血（血尿をも含む）よび尿閉が 圧倒的に多く，55例中それぞれ26例 $(47 \%)$, 計52例 (94 \%) を占めている.（）内の数字は他の症状をも合併 していることを示したものである.

これに反し，陳旧例では95例中，排尿困難が 48 例（50 $\%$ を占め次いで尿閉23例 $(25 \%)$,血尿10例 $(11 \%)$, 尿 瘦 9 例 $(9 \%)$, その他 5 例 $(5 \%)$ で新鮮例に比しおも
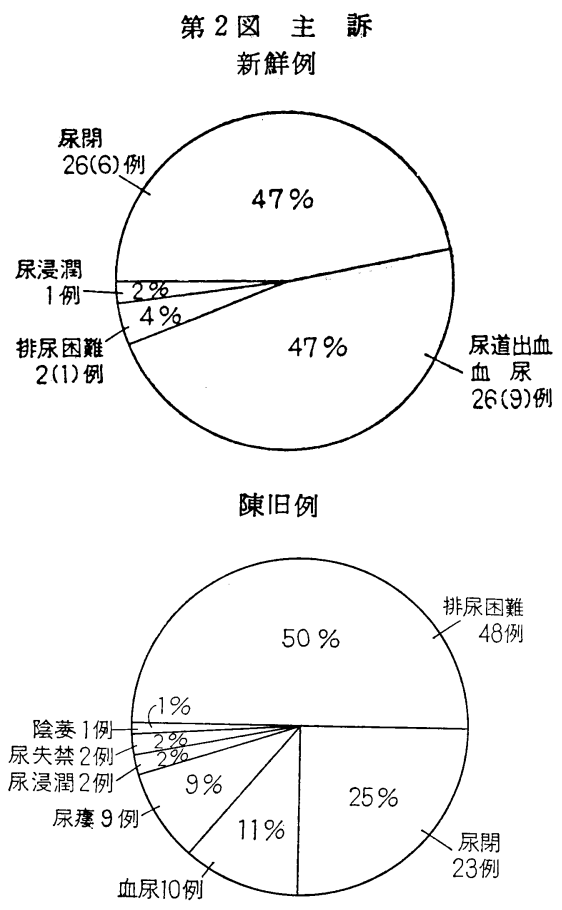

第 3 図男子尿道損傷部位

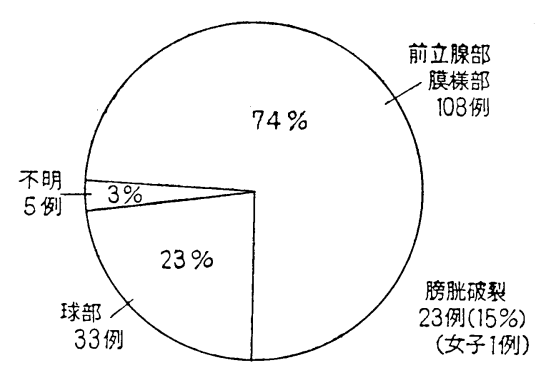

さきを異にしている。

2) 損傷部位

男子尿道の損傷部位は第 3 図に示すごとく, 前立腺 部および膜様部すなわち後部尿道が過半数の 108例（74 \%)を占め，このらち膀胱破裂を伴つたものは23例（25 \%),新鮮例では男女それぞれ 1 例 他の 21 例は全て男子 陳旧例であつた。また前部康道損傷例には膀胱破裂を認 めない.

3）損傷型式

第 4 図は志田 $(1954)^{15)}$ による尿道損傷 の 型に従つて 分類した図であるが全層破裂が 150例中99例（68\%），そ のらち全層不完全破裂は54例 (37\%), 全層完全破裂が45 
第 4 図 尿道損傷の型（志田，1954）

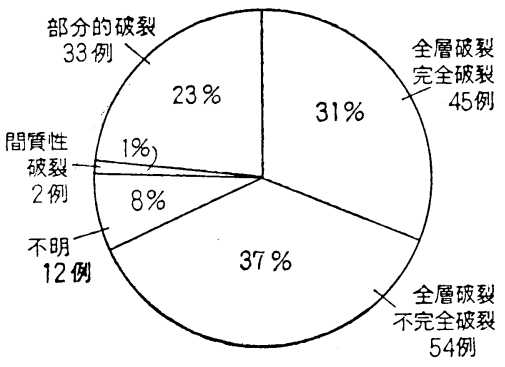

第 5 図 骨折部位

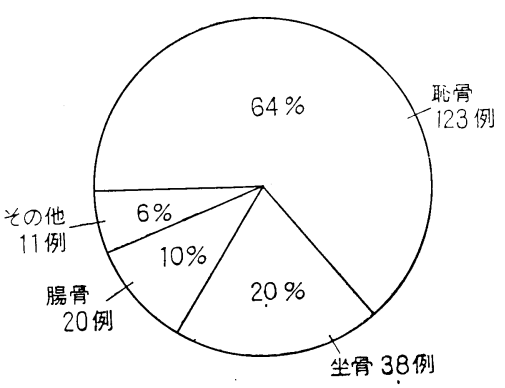

例 (31\%) であつた。次いで部分的破裂33例 $(23 \%)$,間 質性破裂はわずか 2 例（1％）飞過ぎない。

4）骨折部位

骨盤骨折の部位を第 5 図に示すが，恥骨骨折が最も多 く 123例 $(64 \%)$, 次いで坐骨38例 (20\%), 腸骨20例 (10 $\%$ ，その他の部位11例（6\%）,計 192例となるが 2 力所 以上の骨折を含む.

5）治療方法

治療方法は新鮮例と陳旧例では自ずと異るが第 6 図は 両者の治療方法を示したものである．以下新鮮例におい ては女子 2 例を除外して集計した。すすなわち新鮮例53例 では37例 $(70 \%)$,陳旧例では48例 $(51 \%)$ が何らかの外 科的処置を受けていることがわかる.な拉陳旧例では尿 道狭窄に対する治療が主体をなしていると考学られるの で, 新鮮例にはみられない尿道払張術が26例 $(27 \%)$ 存 在する. また留置カテーテルのみの処置を施行したもの は新鮮例で14例 $(26 \%)$,陳旧例では17例 $(18 \%)$ であつ た.

6）外科的処置

外科的処置の内容は第 7 図抽よび第 5 表のごとくで, 男子新鮮例53例中外科的処置を受けたものは37例 (70 \%) で受傷後24時間以内に 28 例 $(53 \%)$ が一次的縫合 術すなわち尿道形成術を受けている。 その術式は pull-
第 6 図 治療方法 新鮮例

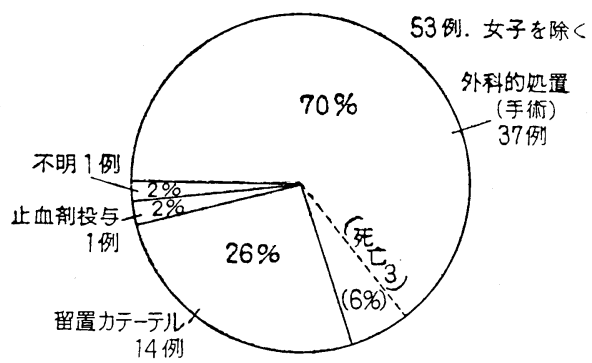

陳旧例

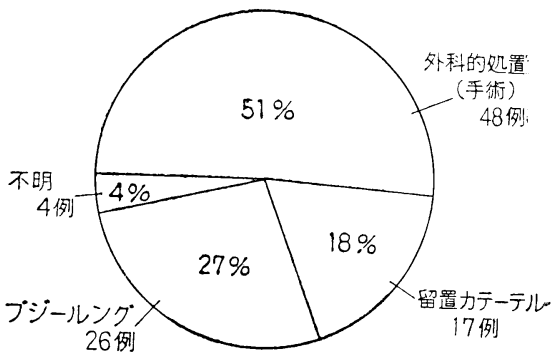

第 7 図. 外科的処置

新鮮例

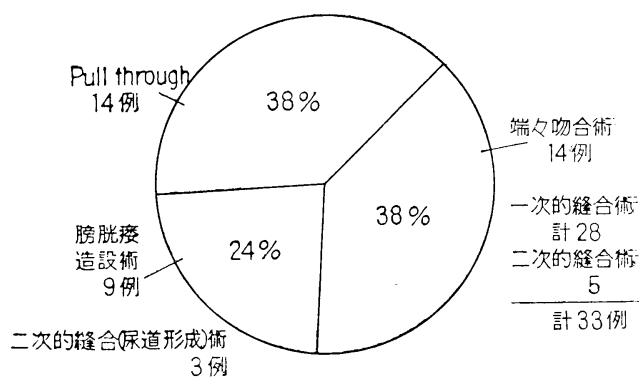

陳旧例

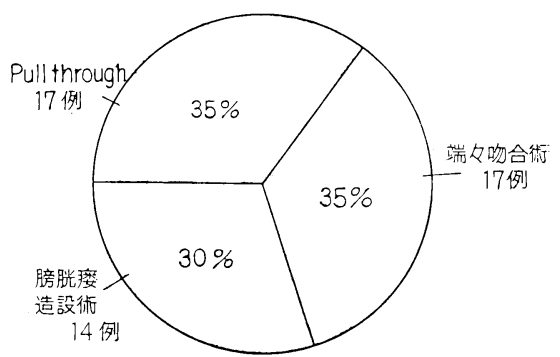

through 手術14例 (38\%),端々吻合術14例（38\%）であ る.これは陳旧例についても同様の傾向を示し. 前者は 17例 $(35 \%)$ ，また後者も17例（35\%）であつた。このよ 
第 8 図 カテーテル留置期間

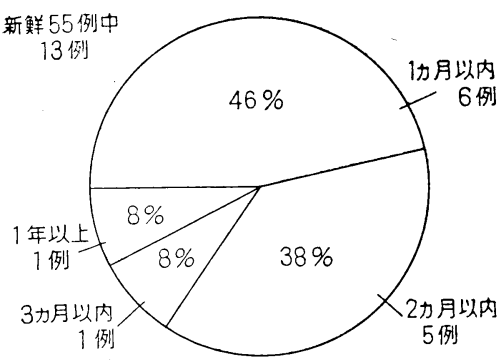

第 9 図 治癒所要日数

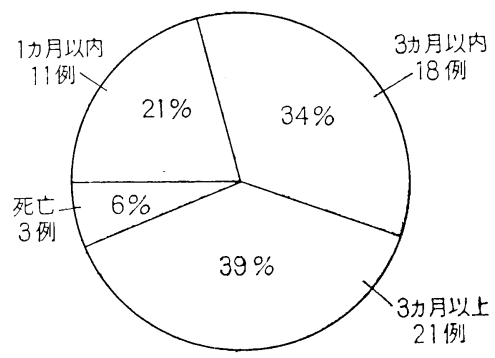

陳昍例

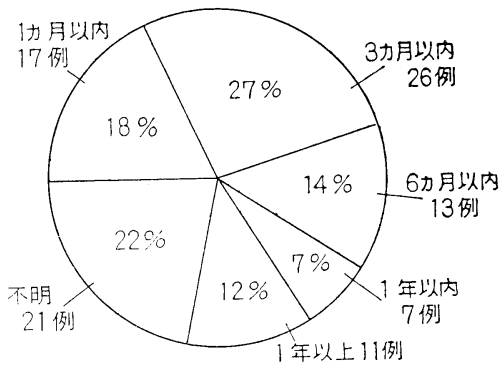

うに新旧ともに雨手術が汪とんど同率に行われている点 は誠に興味深い。

次に受傷直後, 最初の処置として膀胱瘦造設術を受け たものは9例 $(24 \%)$ で，ちち3 例（8.1\%）は後日尿 道形成術を受けている。また受傷直後初回に留置カテー テルのみを施行された14例のらち 2 例がやはり後日に尿 道形成術を受けている。この結果, 新鮮例に持ける尿道 形成術施行例は合計33例（89\%）となる.

一方陳旧例に対する膀脂瘦造設術は14例（30\%）を数 えた。

以上の集計結果より新鮮例に尔いても受傷後初回処置 として膀胱瘦造設術のごとき消極的な処置よりもむしろ 積極的な尿道形成術を施行している場合が遥かに多い （約 3 倍）ことがわかつた。
次に新鮮例53例中確答のあつた13例につき術後カテー テルの留置期間を集計したのが第 8 図であるが，約半数 の 6 例が 1 カ月以内に抜去している.

7) 治癒所要日数

治療期間を第 9 図に示すが，新鮮例においては 29 例 $(55 \%)$, 陳旧例では43例（45\%）が 3 カ月以内に治癒と 判定されている. 受傷後24時間以内に何らかの泌疗器科 的処置を受けた症例の方が治癒所要日数が短いようであ る。

8）経過ならびに予後

第10図に示すごとく新鮮例に少いては27例（51\%） が治癒と判定され，23例 $(43 \%)$ に後遺症を，3 例（6 \%) が受傷後 1 週間以内に死亡している. 一方陳旧例に 牤いては完全治癒と認められたものは 21 例（22\%）, 後遺 症64例 $(67 \%)$ で死亡例は 1 例も認められなかつた。

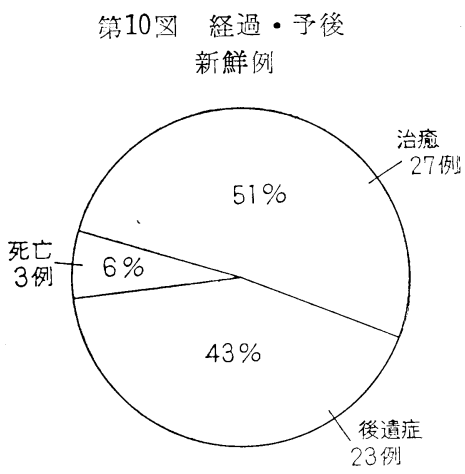

陳旧例

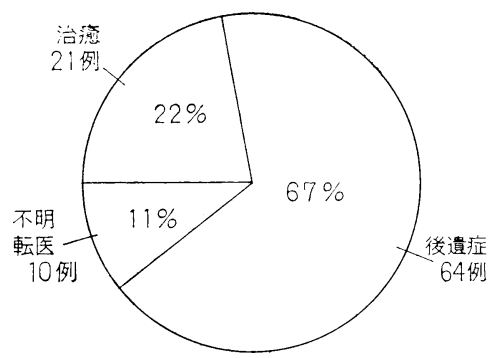

以上の集計結果より受傷直後に適当な処置を施した場 合の方が予後はきわめて良好で後遺定す少いことがおか つた。

9）合併症

本症の主なる合併症についてみるに女子および死亡例 を除く男子新鮮例50例では第11図に示すごとく16例（32 


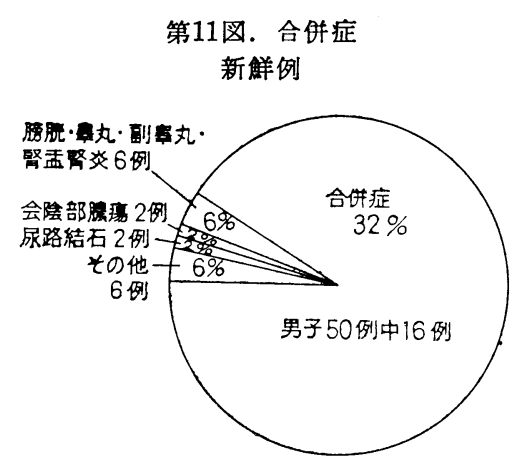

陳旧例

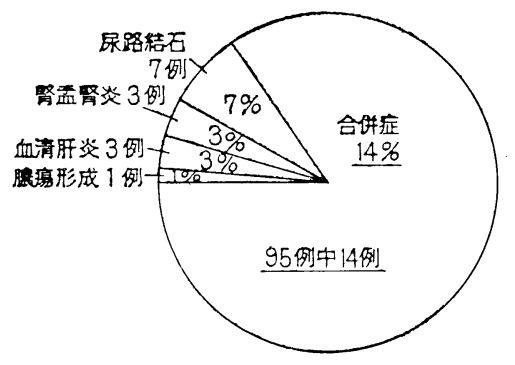

\%)で，その内容は等丸炎，副睪丸炎，膀脂炎および腎 孟腎炎 6 例 $(6 \%)$,会陰部濃瘍 2 例, 結石形成 2 例拈上 びその他として膀脂，直腸破裂，㲾浸潤，無尿，血清肝 炎，再生不良性貧血各 1 例計 6 例となつている。 また陳 旧例では95例中14例（14\%）飞合併症が認められる。す なわち結石形成が最も多く 7 例 $(7 \%)$ を数光, 次いで 腎孟腎炎, 血清肝炎各 3 例（3\%),会陰部膿瘍 1 例（1 \%)の順となっている.

10）後遣症

後遺症に関しては第12図に示すごとく，新鮮例では瘢 痕狭窄が最も多く21例 $(60 \%)$, 次いて陰萎6例 $(18 \%)$, 尿失禁 4 例 $(11 \%)$, 瘦孔形成 2 例 $(8 \%)$, 神経因性膀脱 1 例 ( $3 \%)$,計34例 $(64 \%)$ となつているが，このうち 11例（21\%）は重複せる後遗症を有している．陳旧例に 括いては新鮮例之同様に痗痕性尿道狭窄 が大多数 44 例 (69\%) を占め, 瘦孔形成 9 例 $(13 \%)$, 陰萎 6 例（9 $\%$, 神経因性膀胱 3 例 $(5 \%)$, 尿失禁, 尿道唕室各 1 例（2\%）となつてっる.

すなおち本症に特ける後遺症は尿道の康痕性狭窄が最 も多いがアンケートよりの集計結果では受傷後，ただち に処置を施した方がより良い成績を挙げている。な拉新 旧ともに陰萎が以外に多くみられた。

3 新鮮例

陳旧例に対する処置は尿道狭窄に対する治療が主体を
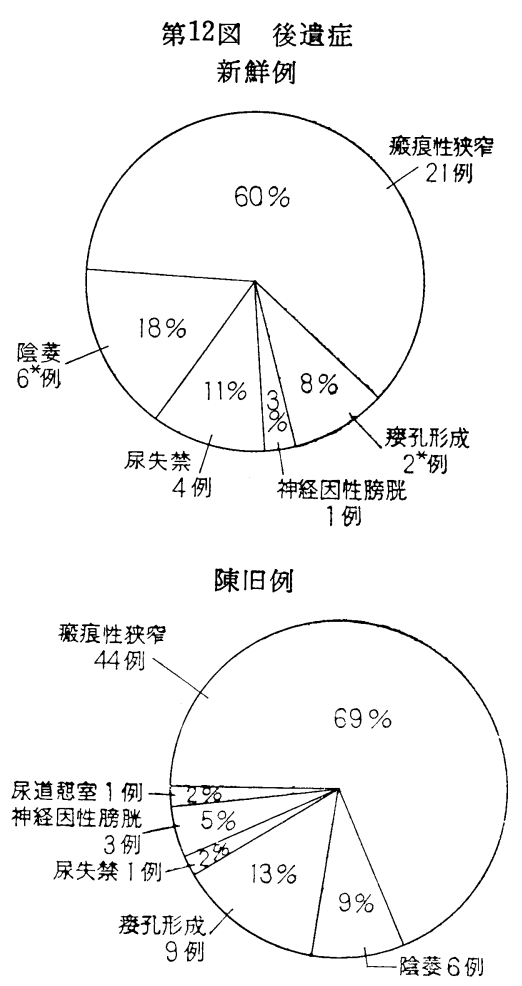

なしているので，ここでは新鮮例すなわち受傷直後の本 症に対していかなる処置が講ぜられ，そしていかなる成 績が得られているかを観察した。な和新鮮例55例中 2 例 の女子症例を除外した男子53例について研究した。

予後判定基準を治療成績から次のごとく4群に分類し た。

第 1 群（有効例）：初回処置後 2 度と治療を必要とせ ず完治したもの.

第 2 群（やや有効例）：初回処置後，排尿困難等の尿 道狭窄症状を生じたため, 度々尿道拉張術を施行してい るもの.

第 3 群（無効例）：2 回以上の外科的処置を必要とし たもの.

第 4 群（死亡例）: 初回処置後 1 週間以内に死亡した もの.

1）受傷後最初の治療法

本症に対する初回処置の内容は第 5 表のごとく，一次 的尿道形成術 28 例 $(52.8 \%)$, 膀胱瘦造設術十留置カテー テルの設置 9 例 $(17.0 \%)$, 留置カテーテル設置のみ 14 例 $(26.4 \%)$,止血剂投与例括よび不明各 1 例 ( $1.9 \%)$ で, 損傷の程度にも大いに関係するが, 半数は受傷後一 
第 5 表 受僨後最初の治瘵方法

\begin{tabular}{|c|c|c|c|c|c|}
\hline 台㾣方法 & 第 1 群 & 第 2 群 & 第 3 群 & 第 4 群 & 計 \\
\hline $\begin{array}{c}1 \text {-成 } \\
\text { 次的尿道形術 }\end{array}$ & $(17)$ & (9) & (2) & & (28) \\
\hline $\begin{array}{l}\text { 1) Pull-through } \\
\text { 手術 }\end{array}$ & 7 & 6 & 1 & 0 & 14 \\
\hline 2)端 々吻合術 & 10 & 3 & 1 & 0 & 14 \\
\hline 2 膀胱瘦造設術 & 2 & 3 & 3 & 1 & 9 \\
\hline $\begin{array}{l}3 \text { 留置カテーテル } \\
\text { 法 }\end{array}$ & 7 & 4 & 2 & 1 & 14 \\
\hline 4 止血㨈 投与 & 1 & 0 & 0 & 0 & 1 \\
\hline 明 & 0 & 0 & 0 & 1 & 1 \\
\hline 総 & 27 & 16 & 7 & 3 & 53 \\
\hline
\end{tabular}

次的に尿道形成術を受けている。

一次的尿道形成術施行例は28例で，その治療成績は第 5 表のごとく第 1 群（有効例）飞属するものが圧倒的に 多く17例 $(60.7 \%)$ を占め, 次いで第 2 群（やや有効 例） 9 例 $(32.1 \%)$ ，第 3 群（無効例） 2 例 $(7.2 \%)$ で，第 4 群（死亡例）は 1 例もなかつた。

以上より，受傷後早期に施行した一次的尿道形成術の 治療成績はきわめて優れた効果を挙げていることがわか つた。

次に膀胱瘦造設術十留置カテーテル法を施行した場合 は第 1 群 2 例 $(22.2 \%)$,第 2 群 3 例 $(33.3 \%)$,第 3 群 3 例 $(33.3 \%)$, 策 4 群 1 例 $(11.1 \%)$ 計 9 例で一次的尿道 形成術に比しその治療効果は良好とい方ない。

留置カテーテル法のみの場合は第 1 群 7 例 $(50.0 \%)$, 第 2 群 4 例（28.6\%）,第 3 群 2 例（14.3\%）, 第 4 群 1 例 ( $7.1 \%)$,計14例で一次的尿道形成術と汪が同じ傾向を 示す。しかしこの場合は尿道損傷の程度が比較的軽度で あることを考慮しなけ讪ばならない。

第 5 表から，第 1 群の例数が多いといらことは（例え ば一次的尿道形成術や留置カテーテル法のごとく）受傷 直後に和计る最初の治療方法がきわめて適切であつたこ とを意味するものと思われる。すすなわち泌尿器科専門医 が勤務している大学附属病院を対象としているために早 期診断および早期の治療法が満足すべきものであつたこ とを示唆している.

2）治療成績と各種の要因

治療成績に関係すると思われる数種の要因について評 価した結果を第 6 表に示す.
第 6 表 治瘵成縉々各要因との関係

\begin{tabular}{|c|c|c|c|c|c|}
\hline & 第 1 群 & 第 2 群 & 第 3 群 & |第 4 群 & 計 \\
\hline \begin{tabular}{|c|} 
a 骨盤骨折の程度 \\
单純骨折
\end{tabular} & 19 & 9 & 2 & 0 & 30 \\
\hline 複雑骨折 & 8 & 7 & 5 & 3 & 23 \\
\hline 計 & 27 & 16 & 7 & 3 & 53 \\
\hline $\begin{array}{l}\mathrm{b} \text { 尿道損㑺の程度 } \\
\text { 部分的破裂 }\end{array}$ & 10 & 2 & 0 & 0 & 12 \\
\hline 不完全破裂 & 7 & 6 & 3 & 1 & 17 \\
\hline 全橧完全破裂 & 10 & 8 & 4 & 2 & 24 \\
\hline 計 & 27 & 16 & 7 & 3 & 53 \\
\hline $\begin{array}{c}\text { c 治癒所要期間 } \\
\text { 力 月以内 }\end{array}$ & 8 & 2 & 1 & 0 & 11 \\
\hline $1 \sim 3$ 力月 & 13 & 5 & 0 & 0 & 18 \\
\hline 3 カ月以上 & 6 & 9 & 6 & 0 & 21 \\
\hline 計 & 27 & 16 & 7 & 0 & 50 \\
\hline $\begin{array}{l}\mathrm{d} \text { 合併症 } \\
\text { 尿性器炎 }\end{array}$ & 4 & 1 & 1 & 0 & 6 \\
\hline 会陰部膿瘍 & 0 & 2 & 0 & 0 & 2 \\
\hline 尿路結石 & 0 & 2 & 0 & 0 & 2 \\
\hline その他 & 2 & 1 & 3 & 0 & 6 \\
\hline 計 & 6 & 6 & 4 & 0 & 16 \\
\hline $\begin{array}{l}\text { 後遗症 } \\
\text { 碳痕性狜窄 }\end{array}$ & 0 & 16 & 5 & 0 & 21 \\
\hline 瘦孔形成 & 1 & 1 & 0 & 0 & 2 \\
\hline 尿失禁 & 3 & 0 & 1 & 0 & 4 \\
\hline 陰 萎 & 3 & 3 & 0 & 0 & 6 \\
\hline 神経因性膀脱 & 0 & 0 & 1 & 0 & 1 \\
\hline 計 & 7 & 20 & 7 & 0 & 34 \\
\hline
\end{tabular}

\section{i . 骨盤骨折の程度}

男子新鮮例53例中単純骨折は30例 $(56.7 \%)$, 複雑骨折 は23例 (43.3\%) で, 治療成績の面からみると第 1 群で は単純骨折19例 $(70.4 \%)$,複雑骨折 8 例 $(29.6 \%)$,第 2 群では16例中単純骨折 9 例 $(56.3 \%)$, 複雑骨折 7 例(43.7 $\%)$, 第 3 群では 7 例中単純骨折 2 例 $(28.6 \%)$, 複雑骨 折 5 例 $(71.4 \%)$,第 4 群では全例（3例）とも複雑骨折 であつた。

骨盤骨折の程度からは複雑骨折例よりも単純骨折例の 方が治療成績は良いようである。

ii . 尿道損傷の程度（型）

予後に最も重要な影響を与えると思われる尿道損傷の 程度と治療成績との関俰をみるに，男子新鮮例では間質 性破裂は 1 例もなく，部分的破裂12例 $(22.6 \%)$,全層不 完全破裂17例 $(32.1 \%)$ ，全層完全破裂24例 (45.3\%) で あつた。すなわち全層破裂が80\%近くを占めている.

さて, 治療成績との関係は，第 1 群では27例中部分的 
破裂10例 $(37.0 \%)$, 全層不完全破裂 7 例 $(26.0 \%)$,全層 完全破裂10例 $(37.0 \%)$ ，第 2 群では16例中部分的破裂 2 例 $(12.5 \%)$,全層不完全破裂 6 例 $(37.5 \%)$,全層完全破 裂 8 例 $(50.0 \%)$, 第 3 群では 7 例中部分的破裂はな く, 全層不完全破裂 3 例 $(42.9 \%)$, 全層完全破裂 4 例 $(57.1 \%)$,第 4 群では，3 例中部分的破裂は 1 例もなく, 全層不完全破裂 1 例 $(33.3 \%)$,全層完全破裂 2 例（66.6 \%)となつている.

すなわち第 1 群では烁道損傷の程度と治療成績との間 にはほとんど差はないが，第 2 群以下では尿道損傷の程 度が大なる汪ど，治療成績は劣る。第 1 群（完治例）で 尿道損傷の程度による差がないことから適切なる診断と 処置によりこの要因はある程度克服することができると 考えたい。

iii. 治癒所要期間

男子新鮮例53例中 11 例 $(20.8 \%)$ が 1 カ月以内に, 18 例 $(34.0 \%)$ が $1 \sim 3$ カ月, 21 例 $(39.6 \%)$ が 3 カ月以 上を要して治癒している。な特 3 例 $(5.6 \%)$ は初回処 置後 1 週間以内に死亡している (第 9 図参照).この死亡 3 例を除外した50例について観察する。

治療成績と治癒所要期間との関係は第 6 表のごとく, 第 1 群では 1 カ月以内に治癒したもの 8 例 $(29.6 \%)$, 1 〜 3 カ月を要したもの 13 例 $(48.2 \%), 3$ カ月以上は 6 例 $(22.2 \%)$, 第 2 群では 1 カ月以内 2 例 $(12.5 \%)$, $1 \sim 3$ 力月以内 5 例 $(31.3 \%), 3$ 力月以上 9 例 $(56.2$ $\%)$, 第 3 群では 1 カ月以内 1 例 $(14.3 \%), 1 \sim 3$ カ月 以内はなく，3カ月以上が 6 例 $(85.7 \%)$ となつてい る.

以上より第 1 群では 3 カ月以内に $77.8 \%$ が治癒してい るが, 第 2 群以下では 3 カ月以上要するものが多い。す なわち第 1 群（完治例）は他群に比し治癒所要期間が短 縮していることがわかつた。

iv. 合併症

第11図に図示したごとく, 死亡 3 例を除く男子新鮮例 50例中主なる合併症を有したものは16例 $(32.0 \%)$ であ り, その内容は尿性器炎 6 例であつて 4 例までが第 1 群 にみられた。次に会陰部膿瘍と尿路結石（膀胱結石）は それぞれ 2 例で, いずれも第 2 群に認められ, しか子尿 路結石の 2 例と会陰部膿瘍の 1 例は膀胱瘦造設術にみら れた。その他として膀胱破裂，直腸破裂，尿浸潤，無 尿，血清肝炎，再生不良性貧血それぞれ 1 例，計 6 例を 認めた.

$\mathrm{v}$. 後遺症
男子新鮮例50例に扣ける後遺症は第 6 表のごとく重複 例を含めて34例 $(68.0 \%)$ であつた.

後遺症としては瘢痕性狭窄が最も多く21例 $(42.0 \%)$, 次いて陰萎 6 例 $(12.0 \%)$, 尿失禁 4 例 $(8.0 \%)$, 瘦孔形 成 2 例 $(4.0 \%)$, 神経因性膀脂 1 例 $(2.0 \%)$ の順とな つている.

これらを治療成績の面からみると, 第 1 群では27例中 陰萎执よび尿失禁がそれぞれ 3 例 $(11.1 \%)$, 瘦孔形成が 1 例 $(3.7 \%)$ で, 瘢痕性狭窄や神経因性膀胱は 1 例む 認められない，次に第 2 群（16例）では全例に痗痕性狭 窄を認め, しかも 3 例に陰萎, 1 例に瘦孔形成を合併 し，延べ20例が後遺症を残している。また第 3 群でも 7 例全例に後遺症を認め， 5 例に瘢痕性狭窄を，1例に尿 失禁， 1 例に神経因性膀胱をみている.

すなわち第 1 群では後遺症は比較的少いが，第 2 およ び第 3 群では全例に後遺症を認める。しかも第 2 群では 他の後遺症を合併している例もあつた。

3）治療方法と治療成績

受傷後最初に施された各種の治療方法とその成績につ いて比較検討した.

i . 一次的尿道形成術と消極的処置

一次的尿道形成術とは受傷後最初に行われた処置が尿 道形成術である場合をいい, pull-through 手術および端 々吻合術に分けた。消極的処置とは膀胱瘦造設術(留置力 テーテルの設置を併用したものも含む) と留置カテーテ ルの設置のみを施行したものを指すことにする.

第 5 表に示すごとく男子新鮮例53例中，一次的尿道形 成術は28例 $(52.8 \%)$ ，また消極的処置は23例 $(43.3 \%)$ に施行されている。

治療成績についてみると，一次的尿道形成術の第 1 群 は，28例中17例 (60.7\%),第 2 群 9 例 $(32.1 \%)$,第 3 群 2 例 $(7.1 \%)$,第 4 群は 0 であつた。消極的処置では第 1 群は23例中 9 例 $(39.1 \%)$,第 2 群 7 例 $(30.4 \%)$,第 3 群 5 例 $(21.7 \%)$,第 4 群 2 例 $(8.7 \%)$ となつている.

このように治療成績の面からみると完治した症例の頻 度より一次的尿道形成術の方が消極的処置よりもすぐれ ていると云兄よう．第 4 群（死亡例）において消極的処 置がとられているのは受傷後の一般的な処置に重点がお かれているものと思われる。第 2 群では闭者ともほ心゙同 率であり, 第 3 群では一次的尿道形成術の方が少い。

次に第 7 表は各種要因との関係から両治療法を比較し たものである。

\section{a . 骨盤骨折の程度}


第 7 表

一次的尿道形成術 (U) : 消極的処置 (C)

\begin{tabular}{|c|c|c|c|c|c|}
\hline & $\left|\begin{array}{c}\text { 第 } 1 \text { 群 } \\
\mathrm{U}: \mathrm{C}\end{array}\right|$ & $\left|\begin{array}{c}\text { 第 } 2 \text { 群 } \\
\mathrm{U}: \mathrm{C}\end{array}\right|$ & $\left|\begin{array}{|c|}\text { 第 } 3 \text { 群| } \\
\mathrm{U}: \mathrm{C}\end{array}\right|$ & $\begin{array}{l}\text { 第 } 4 \text { 君 } \\
\mathrm{U}: \mathrm{C}\end{array}$ & $\begin{array}{c}\text { 竐 } \\
\mathrm{U}: \mathrm{C} \\
\mathrm{U}\end{array}$ \\
\hline \begin{tabular}{|l|}
$\mathrm{a}$ 骨媻骨折の程度 \\
单純骨折
\end{tabular} & $14: 8$ & $6: 3$ & $\mid \begin{array}{lll}0: 1 & 1\end{array}$ & & $20: 12$ \\
\hline 複雑骨折 & $3: 1$ & $3: 4$ & $2: 4$ & $0:$ & $28: 11$ \\
\hline 計 & $17: 9$ & $9: 7$ & $2: 5$ & $0:$ & $2 \overline{28: 23}$ \\
\hline $\begin{array}{c}\mathrm{b} \text { 尿道損矰の程度 } \\
\text { 到分的裂 }\end{array}$ & $2: 7$ & $0:: 1$ & & & $2: 8$ \\
\hline |不完全破裂 & $5: 2$ & $3: 4$ & $0: 3$ & & $8: 9$ \\
\hline 全層完全破裂 & $10: 0$ & $6: 2$ & $2: 2$ & $0:$ & $2 \overline{18: 6}$ \\
\hline 計 & $17: 9$ & $9: 7$ & $2: 5$ & $0:$ & $228: 23$ \\
\hline $\begin{array}{c}\text { c 治癒所要期間 } \\
\text { 力月以内 }\end{array}$ & $4: 3$ & $2: 0$ & $0: 1$ & & $6: 4$ \\
\hline $1 \sim 3$ 力月 & $9: 4$ & $2: 3$ & & & $11: 7$ \\
\hline 3 力月上上 & $4: 2$ & $5: 4$ & $2: 4$ & & $11: 10$ \\
\hline 許 & $17: 9$ & $9: 7$ & $2: 5$ & & $28: 21$ \\
\hline $\begin{array}{l}\mathrm{d} \text { 合併症 } \\
\text { 㽷性器炎 }\end{array}$ & $2: 2$ & $1: 0$ & $1: 0$ & & $4: 2$ \\
\hline 会陰部膿瘍 & & $1: 1$ & & & $1: 1$ \\
\hline 尿路結石 & & $0: 2$ & & & $0: 2$ \\
\hline その他 & $2: 0$ & $0: 1$ & $1: 2$ & & $3: 3$ \\
\hline 計 & $4: 2$ & $2: 4$ & $2: 2$ & & $8: 8$ \\
\hline 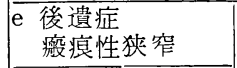 & & $9: 7$ & $1: 4$ & & $10: 11$ \\
\hline 瘒孔形成 & $1: 0$ & $1: 0$ & & & $2: 0$ \\
\hline 尿失禁 & $2: 1$ & & $0: 1$ & & $2: 2$ \\
\hline 陰 萎 & $3: 0$ & $3: 0$ & & & $6: 0$ \\
\hline 神経因性膀胱 & & & $0: 1$ & & $0: 1$ \\
\hline 計 & $6: 1$ & $113: 7$ & $1: 6$ & & $20: 14$ \\
\hline
\end{tabular}

一次的尿道形成施行 28 例中単純骨折は20例 $(71.4 \%)$ ， 複雑骨折は 8 例 $(28.6 \%)$ である. 一方, 消極的処置施 行23例中単純骨折は12例( $52.2 \%$ ), 複雑骨折は11例( 47.8 \%)であつた。

一次的尿道形成術は単純骨折例に多く, 消極的処置は 複雑骨折例飞多く行われている.

次に治療成績からみた両者の比較を行うと, 単純骨折 例に対して行われた一次的尿道形成術 20 例の第 1 群は14 例 $(70.0 \%)$,第 2 群 6 例 $(30.0 \%)$ で, 第 3 群および第 4 群は 1 例もなかつた. 複雑骨折 8 例に打いては第 1 群 および第 2 群が 3 例 $(36.4 \%)$, 第 3 群 2 例 $(27.2 \%)$ と なつている.一方, 消極的処置施行例では単純骨折12例 中第 1 群 8 例 (66.7\%), 第 2 群 3 例 $(25.0 \%)$, 第 3 群は 1 例 $(8.3 \%)$ であり, 複雑骨折11例に打いては第 1 群 1 例 (9.0\%),第 2 - 第 3 群 4 例 $(36.4 \%)$, 第 4 群 2 例 (18.2\%) となつている.
要するに単純骨折例では両者の間に優劣はつけがたい が, 複雑骨折例では一次的尿道形成術の方が良い成績を おさめている.

\section{b . 尿道損傷の程度}

一次的尿道形成術施行 28 例中, 部分的破裂 2 例 $(7.1$ $\%)$,全層不完全破裂 8 例 $(28.6 \%)$,全層完全破裂は18例 (64.3\%) であり，消極的処置施行 23 例では部分的破裂 8 例 $(34.7 \%)$, 全層不完全破裂 9 例 $(39.1 \%)$, 全層完全 破裂 6 例 $(26.2 \%)$ であつた.

一次的尿道形成術の大半は主として全層完全破裂例に 施行されているが，これに反し消極的処置は部分的破裂 と全層不完全破裂例に多く用いられ，完全破裂例は最も 少かつた.

次に治療成績から比較検討すると，

（1）部分的破裂：一次的尿道形成術は 2 例に行われ ているが全例とも完全治癒（第1群）している.消極的 処置群では 8 例あるが第 1 群は 7 例 $(87.5 \%)$,第 2 群は 1 例 $(12.5 \%)$ であつた。

（2）全層不完全破裂：一次的尿道形成術が 8 例又ら れるが第 1 群 5 例 $(62.5 \%)$,第 2 群は 3 例 $(37.5 \%)$ ，であ つた. 消極的処置は 9 例に施行され，第 1 群 2 例 $(22.2$ $\%)$, 第 2 群 4 例 $(44.4 \%)$, 第 3 群 3 例 $(33.3 \%)$ となつ ている。

（3）全層完全破裂：一次的尿道形成術18例中，第 1 群10例 $(55.6 \%)$, 第 2 群 6 例 $(33.3 \%)$, 第 3 群は 2 例 (11.1\%) であり,消極的処置は 6 例て行われて拉り,第 1 群はないが第 2 ・3・4 群がそれぞれ 2 例 (33.3\%) であつた。

すなわち尿道損傷の程度と治療成績の面から比較検討 した結果, 部分的破裂に関しては一次的尿道形成術, 消 極的処置ともに良い成績を得ている. 全層不完全破裂で は一次的尿道形成術がすぐれている．特に全層完全破裂 に対しては一次的尿道形成術がはるかにすぐれた成績を あげている.

c. 治癒所要期間

一次的尿道形成術施行 28 例中, 1 力月以内に治癒した ものは 6 例 $(21.6 \%), 1 \sim 3$ カ月以内が11例 $(39.2 \%)$, 3 カ月以上はやはり11例 $(39.2 \%)$ となつている.消極 的処置施行例に执いては23例中， 2 例が死亡しているの でこれを除外した 21 例について検討するに，1 カ月以 内は 4 例 $(19.0 \%), 1 \sim 3$ 力月 7 例 $(33.3 \%), 3$ カ月以 上10例 $(47.6 \%)$ となり，3 カ月以内の治癒率は一次的 尿道形成術では $60.8 \%$, 消極的処置例では $52.3 \%$ 々やや 
一次的尿道形成術の方がすぐれている.

次に治癒成績から検討すると，

（1） 1 カ月以内の治㾤率：一次的尿道形成術では, 1 力月以内に 28 例中 6 例 $(21.6 \%)$ が治瘾しているが, 第 1 群は 4 例 $(66.7 \%)$, 第 2 群は 2 例 $(33.3 \%)$ であ り, 消極的処置例では21例中 4 例 $(19.0 \%)$ で, 第 1 群 3 例 $(75.0 \%)$,第 3 群 1 例 $(25.0 \%$ となつている.

（2） 1 3 カ月の治癒率 : 一次的尿道形成術の第 1 群は11例中 9 例 $(82.0 \%)$,第 2 群 2 例 $(18.0 \%)$, 消極的 処置例では 7 例中第 1 群は 4 例 $(57.1 \%)$, 第 2 群 3 例 (42.9\%) であつた.

（3） 3 カ月以上の治癒率：一次的尿道形成術では11 例中第 1 群 4 例 (36.4\%), 第 2 群 5 例 $(45.5 \%)$,第 3 群 2 例 $(18.2 \%)$, 消極的処置例では10例中第 1 群 2 例(20.0 $\%)$,第 $2 \cdot 3$ 群ともに 4 例 (40.0\%) となつている.

以上より両者の第 1 群に和ける 1 カ月以内の治癒率は 消極的処置例がやや良く，1 3 カ月の治癒率は一次的 尿道形成術がはるかにすぐれている.すなわち一次的尿 道形成術の方が完治例が多いことがわかつた。

d. 合併症

一次的尿道形成術28例中合併症を有したものは8例 (28.5\%) で，その内容は尿性器炎 4 例 $(50.0 \%)$,会陰 部膿瘍 1 例 $(12.5 \%)$ ，その他 3 例 ${ }^{\prime}(37.5 \%)$ となつてい る. 消極的処置においては死亡 2 例を除く21例中合併症 は 8 例 $(38.1 \%)$ であり，その詳細は泌尿性器炎 2 例 $(25.0 \%)$,会陰部膿瘍 1 例 $(12.5 \%)$, 尿路（膀脱）結石 2 例 $(25.0 \%)$,その他 3 例 (37.5\%) であつた.

次に治療成績別にみると一次的尿道形成術では合併症 8 例中, 第 1 群が 4 例 $(50.0 \%)$,第 2 ・3 群がそれぞれ 2 例 $(25.0 \%)$, 消極的処置では同じく8例で，第 $1 \cdot 3$ 群がそれぞれ 2 例 $(25.0 \%)$,第 2 群 4 例 $(50.0 \%)$ とな つている。

e. 後遺症

一次的尿道形成術 28 例中，後遗症は重複例を含め 20 例 (71.4\%) で，その内容は瘚痕性狭窄10例 $(35.7 \%)$,瘦 孔形成特よび尿失禁がそれぞれ 2 例 $(7.1 \%)$,陰萎 6 例 (21.4\%) であり，消極的処置では21例中14例（66.7 \%) 飞後遺症をみ，瘤痕性狭窄が11例 $(52.4 \%)$,尿失禁 2 例 $(9.5 \%)$, 神経因性膀脂 1 例（ $4.8 \%)$ となつてい る.

すなわち後遺症は一次的尿道形成術にやや多く，特に 陰萎は全例とも一次的尿道形成術施行例飞認められた。

次に両処置を治療成績から比較してみると，一次的尿
道形成術の第 1 群は28例中17例（60.7\%）であるが，そ のうち 6 例 $(35.3 \%)$ に後遺症を認める. その内容は瘦 孔形成が 1 例，尿失禁 2 例，陰萎 3 例である。 これに対 して消極的処置群では，第 1 群は死亡 2 例を除く21例 中 9 例 $(42.9 \%)$ で，後遺症はわずかに尿失禁の 1 例 (11.1\%) であつた。第 2 群では一次的尿道形成術は 9 例 $(32.1 \%)$ で，全例に後遺症として尿道狭窄をみ，し かも陰萎 3 例と瘦孔形成 1 例が合併している. 一方, 消 極的処置群における第 2 群は 7 例 $(33.3 \%)$ で,やはり 全例に尿道狭窄を認めるが，その他の後遺症は合併して いなかつた．第 3 群は一次的尿道形成術 2 例（ $7.2 \%)$ で, 後遣症は尿道狭窄の 1 例のみである。また消極的処 置群は 5 例 $(23.8 \%)$ で, 全例に後遺症として尿道狭窄 4 例，尿失禁 1 例を認め，そのうち 1 例に神経因性膀脱 を合併している。

以上を要約すると，第 1 群では一次的尿道形成術に後 遺症を多く認め, これは消極的処置の約 3 倍に当る( 35.3 $\%: 11.1 \%)$. 第 2 群では両者とも全例に尿道狭窄を認 第 8 表

Pull-through 手術 $(P)$ : 端々吻合術 $(E)$

\begin{tabular}{|c|c|c|c|c|c|}
\hline & $\left|\begin{array}{llll}\mid & \text { 第 } & \text { 群 } \\
\mathrm{P} & : & \mathrm{E}\end{array}\right|$ & $\left|\begin{array}{lll}\mid & \text { 第 } & \text { 群 } \\
\mathrm{P} & : & \mathrm{E}\end{array}\right|$ & $\mid \begin{array}{lll}\text { 第 } & 3 & \text { 群 } \\
\mathrm{P} & : & \mathrm{E}\end{array}$ & 第 4 群 & 珜 $\mathrm{P}$ 計 \\
\hline $\begin{array}{l}\text { a 骨盤骨折の程度 } \\
\text { 单純骨折 }\end{array}$ & $7: 7$ & $4: 2$ & & & $11:$ \\
\hline 複雑骨折 & $0: 3$ & $2: 1$ & $1: 1$ & & $3:$ \\
\hline 計 & $7: 10$ & $6: 3$ & $1: 1$ & & 14: \\
\hline $\begin{array}{l}\text { 尿道損傷 } \\
\text { 部分的破 }\end{array}$ & $1: 1$ & & & & 1: \\
\hline 全属 不完全破裂 & $3: 2$ & $2: 1$ & & & $5:$ \\
\hline 至谓完 全 破裂 & $3: 7$ & $4: 2$ & $1: 1$ & & $8: 10$ \\
\hline 計 & $7: 10$ & 6 & $1: 1$ & & $14:$ \\
\hline 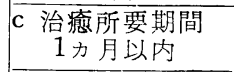 & $2: 2$ & $2: 0$ & & & 4: \\
\hline $1 \sim 3$ 力月 & $4: 5$ & $2: 0$ & & & $6:$ \\
\hline 3力月以上 & $1: 3$ & $2: 3$ & $\overline{1: 1}$ & & 4: \\
\hline 計 & $7: 10$ & $6: 3$ & $1: 1$ & & $14: 1$ \\
\hline $\begin{array}{l}d \text { 合併症 } \\
\text { 㗊性炎 }\end{array}$ & $1: 1$ & $1: 0$ & $1: 0$ & & $3: 1$ \\
\hline 会陰部膿場 & & $1: 0$ & & & $1:$ \\
\hline その他 & $0: 2$ & & $0: 1$ & & $0:$ \\
\hline 計 & $1: 3$ & $2: 0$ & $1: 1$ & & $4:$ \\
\hline $\begin{array}{l}\mathrm{e} \text { 後遺症 } \\
\text { 洀痕性狭窄 }\end{array}$ & & $6: 3$ & $1: 0$ & & $7:$ \\
\hline 瘦孔形成 & $1: 0$ & $0: 1$ & & & 1: \\
\hline 尿失禁 & $0: 2$ & & & & $0:$ \\
\hline 㓌 萎 & $2: 1$ & $3: 0$ & & & $5:$ \\
\hline 計 & $3: 3$ & $9:$ & $1: 0$ & & $3:$ \\
\hline
\end{tabular}


め，その比はほよ゙同率であるが $(32.1 \%: 33.3 \%)$,特に 一次的尿道形成術では他の後遺症を合併した例が $44.4 \%$ 存在する. 消極的処置群にはかかる例はなかつた. 第 3 群においては一次的尿道形成術の方が後遺症ははるかに 少かつた。

ii . Pull-through 手術之端々吻合術

第 5,8 表のごとく男子新鮮例53例中, 一次的尿道形 成術として pull-through 手術14例 (26.4\%) および 端 々吻合術14例 $(26.4 \%)$, 計28例 (52.8\%) が施行され, 両者は全く同数となつている.

この両手術を治療成績と各種の要因とから比較したの が第8表である.

Pull-through 手術においては, 第 1 群は14例中 7 例 $(50.0 \%)$,第 2 群 6 例 $(42.9 \%)$, 第 3 群 1 例 $(7.1 \%)$ であり，端々吻合術では14例中第1 群10例（71.4\%),第 2 群 3 例 $(21.4 \%)$,第 3 群 1 例 $(7.1 \%)$ となり, 治療 成績からは pull-through 手術よりも端々吻合術の方が 良い結果を示している。

主なる要因との関係 (第 8 表参照).

a . 骨盤骨折の程度

Pull-through 手術施行14例中単純骨折は11例 (78.6 $\%)$, 複雑骨折 3 例 (21.4\%) である。一方, 端々吻合術 に打いては単純骨折 9 例 (64.3\%), 複雑骨折 5 例 (35.7 \%)となつている.すなわち両処置はいずれも単純骨折 に対して多く用いられているが, 複雑骨折に対しては pull-through 手術よりも端々吻合術の方がより多く施さ れている傾向がうかがわれた.

次に治療成績について比較すると単純骨折に対して施 行された pull-through 手術は11例であり, 第 1 群 7 例 $(63.6 \%)$,第 2 群 4 例 $(36.4 \%)$ と完治例が多い. 複雑 骨折では 3 例に用いられており，第 2 群 2 例 $(66.7 \%)$, 第 3 群 1 例 (33.3\%) で完治例はなかつた. 一方, 端々 吻合術では単純骨折 9 例中, 第 1 群 7 例 $(77.8 \%)$,第 2 群 2 例 $(22.2 \%)$ でやはり完治例が多い。また複雑骨折 には 5 例が施行されているが，第 1 群 3 例 $(60.0 \%)$ 第 2 扣よび第 3 群は，それぞれ 1 例（20.0\%）となつてい る.

すなわち単純骨折に対する両術式の治療成績はほとん ど同率で優劣はつけがたい. しかし複雑骨折では明らか に端々吻合術が良い成績を挙げている。

b . 尿道損傷の程度

Pull-through 手術14例中部分的破裂 1 例 $(7.1 \%)$,全
層不完全破裂 5 例 (35.7\%), 全層完全破裂は 8例 (57.2: $\%)$ であり，端々吻合術では14例中部分的破裂 1 例 7.1 $\%)$, 全層不完全破裂 3 例 (21.4\%), 全層完全破裂10例! (71.4\%) となり，両者とも全層完全破裂に対してょり， 多く行われている.

次に治療成績から検討すると，

（1）部分的破裂：両術式とも1例づつ行われて护 り，いずれも第 1 群に属している.

（2）全層不完全破裂：Pull-through 手術は 5 例に 行われており，第 1 群 3 例 (60.0\%), 第 2 群 2 例 (40.0 \%) となつている. 端々喘合術は 3 例で, らち第 1 群 2 例 $(66.7 \%)$,第 2 群 1 例 $(33.3 \%)$ となり両術式の治療 成績に対する差はほとんどない。

（3）全層完全破裂: Pull-through 手術は8例行わ. れている。すすなわ第 1 群 3 例 (37.5\%), 第 2 群 4 例 $(50.0 \%)$,第 3 群 1 例 $(12.5 \%)$ である。また端々吻合 術は10例行われて扣り，第 1 群 7 例 $(70.0 \%)$,第 2 群 2 例 $(20.0 \%)$, 第 3 群 1 例 $(10.0 \%)$ となり pull-through 手術に対乙端々吻合術が良い成績を蛙さめている。

上記より，両術式は部分的破裂と全層不完全破裂に対 しては汪とんど同じ治療成績を示しているが，全層完全 破裂に怙いては端々吻合術の方がはるかにすぐれている と云えよう。

\section{c . 治瘾所要期間}

pull-through 手術施行14例中 1 力月以内の治癒率は 4 例 $(28.6 \%), 1 \sim 3$ 力月は 6 例 $(42.8 \%), 3$ 力月以上 は 4 例 $(28.6 \%)$ であり, 端々吻合術では14例中 1 カ月 以内は 2 例 $(14.3 \%), 1 \sim 3$ 力月 5 例 $(35.7 \%), 3$ 力月 以上 7 例 $(50.0 \%)$ となり治癒率に関しては pull-through 手術の方が短期間に治癒する傾向を示している. 治療成績から検討するに，

（1） 1 カ月以内の 治癒率 : Pull-through 手術では 1 カ月以内に 14 例 4 例 $(28.6 \%)$ が治癒しているが, 第 1 群をみると 2 例 $(50.0 \%)$,第 2 群も同じく 2 例 $(50.0$ \%) となり，端々吻合術では14例中 2 例 $(14.3 \%)$ が治 癒しているに過ぎずいずれも第 1 群であつた.

(2) $1 \sim 3$ カ月以内の治癒率 : Pull-through 手術 は 6 例で第 1 群 4 例 (66.7\%), 第 2 群 2 例 $(33.3 \%)$ で あり, 端々吻合術は 5 例で全て第 1 群であつた。

（3） 3 カ月以上の 治癒率: Pull-through 手術は 4 例で第 1 群 1 例 (25.0\%), 第 2 群 2 例 $(50.0 \%)$,第 3 群 1 例 $(25.0 \%)$,端々吻合術は 6 例で第 1 , 第 2 群ともに 3 例 $(42.9 \%)$,第 3 群 1 例（14.2\%）となつている. 
第 1 群に拈ける 3 カ月以内 の 治癒率は pull-through 手術が 7 例中 6 例 $(85.6 \%)$, 端々吻合術は 10 例中 7 例 (70.0\%) で，治療成績からも pull-through 手術の方 が良い結果を示している.

d . 合併症

Pull-through手術，端々吻合術ともに主なる合併症を 有したのは 4 例 $(28.6 \%)$ で，その内容は pull-through 手術群では尿性器炎 3 例 $(21.4 \%)$, 会陰部膿瘍 1 例 (7.1 \%) であり, 端々吻合術群では尿性器炎 1 例 $(7.1 \%)$, その他 3 例 $(21.4 \%)$ となつている.

治療成績の面からは pull-through 手術群では第 1 群 飞尿性器炎を, 第 2 群では尿性器炎, 会陰部膿瘍各 1 例, 第 3 群では尿性器炎 1 例であつた。端々吻合術では 第 1 群に尿性器炎 1 例, その他 2 例, 第 3 群ではその他 1 例をみている。

e. 後遺症

Pull-through 手術14例中後遺症は重複例を含め13例 (92.9\%) で，その内容は瘢痕性狭窄 7 例 $(50.0 \%)$, 瘦 孔形成 1 例 $(7.1 \%)$,陰萎 5 例 $(35.7 \%)=5$ ち 2 例は 重複例=であり，端々吻合術では14例中 7 例 $(50.0 \%)$ 记後遗症をみ，瘦痕性狭窄 3 例 $(21.4 \%)$, 瘦孔形成 1 例 $(7.1 \%)=$ 重複例=, 尿失禁 2 例 $(14.3 \%)$, 陰萎 1 例 ( $7.1 \%)$ であつた.

後遺症は pull-through 手術に圧倒的に多く, 端々吻 合術の約 2 倍に相当している. 特に陰萎は pull-through 手術例に多く, 端々吻合術の 5 倍にも達している。また 洀痕性狭窄も pull-through 手術に多い。乙かし尿失禁 は全て端々吻合術にのみ認められた。

次飞両術式を治療成績から比較してみると pull-through 手術例の第 1 群は 14 例中 7 例: (50.0\%) で，その らち 3 例 $(42.9 \%)$ 飞後遺症を認める.すなわち瘦孔形 成 1 例 $(14.2 \%)$, 陰萎 2 例 (28.6\%) であつた。 これに 対して, 端々吻合術群では第 1 群は14例中10例 (71.4 \%)で，3例 $(30.0 \%)$ 飞後遺症を認める.すなわち尿 失禁 2 例 $(20.0 \%)$,陰萎 1 例 (10.0\%) であつた.

次に第 2 群では pull-through 手術は 6 例 $(42.8 \%)$ に施行されているが, 全例に後遺症を認め, しかも 3 例 が他の後遺症（陰萎）を合併している. 端々吻合術は 3 例 $(21.4 \%)$ であるが，やはり全例に後遺症をみ，らち 1 例飞瘦孔形成を合併している.

第 3 群は pull-through手術の 1 例 ( $7.1 \%)$ のみで, 洀痕性狭窄の後遺症を認める.

以上を要約すると, 各群における後遺症の頻度は端々
第 9 表

膀胱瘦造設術（C）：留置カテーテル法 (I)

\begin{tabular}{|c|c|c|c|c|c|}
\hline & \multicolumn{5}{|c|}{ 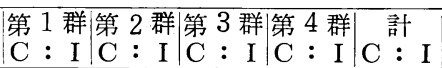 } \\
\hline $\begin{array}{l}\text { a 骨盤骨折の程度 } \\
\text { 㫮純骨折 }\end{array}$ & $1: 7$ & $0: 3$ & $1: 0$ & & $2: 10$ \\
\hline 複雑骨折 & $1: 0$ & $3: 1$ & $2: 2$ & $1: 1$ & $7: 4$ \\
\hline 計 & $2: 7$ & $3: 4$ & $3: 2$ & $1: 1$ & $19: 14$ \\
\hline $\begin{array}{l}\mathrm{b} \text { 尿道損傷の程度 } \\
\text { 部分的破裂 }\end{array}$ & $2: 5$ & $0: 1$ & & & $2: 6$ \\
\hline 屏不完全破裂 & $0: 2$ & $1: 3$ & $1: 2$ & & $2: 7$ \\
\hline 全層完全破裂 & & $2: 0$ & $2: 0$ & $1: 1$ & $5: 1$ \\
\hline 計 & $2: 7$ & $3: 4$ & $3: 2$ & $1: 1$ & $\overline{9: 14}$ \\
\hline $\begin{array}{c}\mathrm{c} \text { 治癒所要期間 } \\
1 \text { 出以内 }\end{array}$ & $0: 3$ & & $1: 0$ & & $1: 3$ \\
\hline $1 \sim 3$ 力月 & $1: 3$ & $1: 2$ & & & $2: 5$ \\
\hline 3 力月以上 & $1: 1$ & $2: 2$ & $2: 2$ & & $5: 5$ \\
\hline 計 & $2: 7$ & $3: 4$ & $3: 2$ & & $8: 13$ \\
\hline $\begin{array}{l}\mathrm{d} \text { 合併症 } \\
\text { 尿性器炎 }\end{array}$ & $0: 2$ & & & & $0: 2$ \\
\hline 会陰部膿瘍 & & $1: 0$ & & & $1: 0$ \\
\hline 尿路結石 & & $2: 0$ & & & $2: 0$ \\
\hline その他 & & $0: 1$ & $1: 1$ & & $1: 2$ \\
\hline 計 & $0: 2$ & $3: 1$ & $1: 1$ & & $4: 4$ \\
\hline \begin{tabular}{|l}
$\mathrm{e}$ 後遗症 \\
洀痕性狭窄
\end{tabular} & & $3: 4$ & $2: 2$ & & $5: 6$ \\
\hline 瘦孔形成 & & & & & \\
\hline 尿失禁 & $0: 1$ & & $1: 0$ & & $1: 0$ \\
\hline 陰 萎 & & & & & \\
\hline 神経因性膀胱 & & & $1: 0$ & & $1: 1$ \\
\hline 計 & $0: 1$ & $\overline{3: 4}$ & $4: 0$ & & $7: 7$ \\
\hline
\end{tabular}

吻合術の方が少いことがわかつた.

iii. 膀胼瘦造設術と留置カテーテル法

第 5 抢よび 9 表のごこく, 男子新鮮例53例中膀胱瘦造 設術は 9 例 $(16.9 \%)$, 留置カテーテル法は 14 例 $(26.4$ $\%)$,計23例 $(43.3 \%)$ が施行されている.

この両処置の治療成績と各要因との関係を第 9 表に示 す.

すなわち膀胱瘦造設術の第 1 群は 2 例 $(22.2 \%)$,第 2 群 3 例 (33.3\%), 第 3 群 3 例(33.3\%), 第 4 群 1 例(11.1 \%) である. 一方, 留置カテーテル法の第 1 群は 7 例 (50.0\%),第 2 群 4 例 $(28.6 \%)$, 第 3 群 2 例 $(14.3 \%)$, 第 4 群 1 例 ( $7.1 \%$ ） となつている. 両者とも第 4 群 (死亡例) が 1 例づつ存在する.

全般的に両者を比較すると明らかに留置カテーテル法 がよい成績を和さめているようにみえるが，これは数字 の上から云えることで，それらの内容，すなわち骨折や 
尿道損傷の程度を十分考慮しなければならない。

そこで，第 9 表に示す主なる要因との関係を検討して みよう。

a . 骨盤骨折の程度

単純骨折例に対する膀胱㾇造設術は 9 例中 2 例 $(22.2$ $\%)$,留置カテーテル法は14例中10例 $(71.4 \%)$ で, 留置 カテーテル法が圧倒的に多い。すなわち留置カテーテル 法施行例は骨盤骨折の程度の軽いものに，逆に膀脱瘦造 設術は骨盤骨折の程度の重い例飞施行されていることが わかる。

次に治療成績に対する両者の比較を行うと，単純骨折 例における膀胱瘦造設術は第 1 および第 3 群にとれぞれ 1 例 $(50.0 \%)$, 留置カテーテル法は10例中第 1 群が 7 例 (70.0\%),第 2 群 3 例（30.0\%）で明らかに留置カテー テル法がすぐれているといえよう。

複雑骨折例飞执いては, 膀胱瘦造設術は 7 例中第 1 群 が 1 例 (14.2\%),第 2 群 3 例(42.9\%), 第 3 群 2 例(28.6 $\%)$,第 4 群 1 例 (14.2\%) となり，第 2 ・第 3 群が 7 例 中 5 例 $(71.5 \%)$ を占めている.

また留置カテーテル施行例は 4 例であるが，第 1 群は なく，第 2 ・第 4 群にそれぞれ 1 例 $(25.0 \%)$,第 3 群に 2 例 $(50.0 \%)$ 又られ，やはり第 2 ・第 3 群が 4 例中 3 例 $(75.0 \%)$ を占めている.

要するに，単純骨折で留置カテーテルの治療成績がす ぐれているのは，尿道損傷の程度が軽いことを推測させ る. 一方, 複雑骨折例では膀胱瘦造設術と留置カテーテ ル法との間には著明な差はない。

b . 尿道損傷の程度

膀胱瘦造設術は部分的拈よび全層不完全破裂に対して 9 例中それぞれ 2 例 $(22.2 \%)$,全層完全破裂に対して 5 例 $(55.6 \%)$ 行われている.

一方, 留置カテーテル法は14例中, 部分的破裂に 6 例 (42.9\%), 全層不完全破裂に 7 例 $(50.0 \%)$,全層完全破 裂に1例 $(7.1 \%)$ 施行されている.

すなわち，尿道損傷の程度からみるに，膀胱㾞造設術 は主江全層完全破裂例に多く施行され, 留置カテーテル 法は程度の軽い部分的破裂や全層不完全破裂例に多い。 治療成績からは，

（1） 部分的破裂：膀胱㾞造設術では 9 例中2例(22.2 \%）にみられ，いずれも第 1 群であつた．留置カテーテ ル法は14例中 6 例 $(42.9 \%)$ 飞施行されて打り，らち 5 例 $(35.7 \%)$ が第1 群で， 1 例 $(7.1 \%)$ が第 2 群であ つた。
（2）全層不完全破裂：第 1 群は留置カテーテル法の 2 例 $(14.3 \%$ ）のみである. 第 2 群は膀腃瘦造設術 1 例 $(11.1 \%)$,留置カテーテル法 3 例 $(21.4 \%)$,第 3 群では 膀胀瘻造設術 1 例( $11.1 \%$ ), 留置カテーテル法 2 例(14.3 \%) であつた.

（3）全層完全破裂：第 1 群は両者ともなく，第 2 打 よび第 3 群では膀脱瘦造設術を 2 例 $(22.2 \%)$ 認めるの みで，留置カテーテル法は 1 例もない，第 4 群に打い ては膀胱瘦造設術 1 例 $(11.1 \%)$, 留置 カテーテル法 1 例 ( $7.1 \%)$ を認めた。

尿道損傷の比較的軽い部分的破裂や全層不完全破裂に 対しては留置カテーテル法が多く用いられ, 治癒率も膀 胱瘦造設術に比べてすぐれている. 全層完全破裂に対し ては膀脱瘦造設術のみが施行されているが，治療成績は 良好とは云えない，死亡例に対して両者が 1 例づつ行わ れているのは，多分姑息的な手段としてこれらの処置が 用いられたものと思われる。

\section{c . 治癒所要期間}

死亡 2 例を除く 21 例に拈ける治瘾所要期間について検 討する.

膀脱瘦造設術施行 8 例中, 1 カ月以内の治癒率は 1 例 $(12.5 \%), 1 \sim 3$ カ月は 2 例 $(25.0 \%), 3$ カ月以上は 5 例 $(62.5 \%)$ であり,これに対して留置カテーテル施行 例では13例中， 1 力月以内 3 例 $(23.0 \%), 1 \sim 3$ 力月 5 例 $(38.5 \%), 3$ カ月以上 5 例 $(38.5 \%)$ となり，3 カ月 以内の治癒率は留置カテーテル法が $61.5 \%$ と膀胱瘦造影 術（37.5\%）よりも良い成績を扣さめている。 次に治療成績から比較すると，

（1） 1 カ月以内の治癒率 : 第 1 群で 1 カ月以内に治 癒している例は 3 例 $(33.3 \%)$ で, いずれも留置カテー テル法によるものであつた．第 2 群は両者ともになく， 第 3 群は 5 例中 1 例 $(20.0 \%)$ を認めるが，これは膀胖 癭造設術施行例である.

（2） 1 ～ 3 カ月の治癒率：第 1 群は 4 例 $(44.4 \%)$ で膀胱瘻造設術 1 例 $(11.1 \%)$, 留置カテーテル法 3 例 (33.3\%) を認める.第 2 群は 3 例 $(42.9 \%)$ であるが 膀胱瘦造設術が 1 例 $(14.2 \%)$, 留置カテーテル法が 2 例 (28.5\%) であつた。

（3） 3 カ月以上の治癒率 : 第 1 群は両者それぞれ 1 例 $(11.1 \%)$ であり，第 2 および第 3 群は両者ともに 2 例 $(22.2 \%)$ づつを認めた。

要するに, 第 1 群に括ける 3 カ月以内の治癒率は 9 例 中 2 例 $(22.2 \%)$ が膀胖㿉造設術で， 7 例 $(77.8 \%)$ が 
留置カテーテル法であつた．やはり治療成績からの比較 によつても留置カテーテル法が好成績をおさめている.

d. 合併症

第 9 表のごとく，膀脱㾇造設術と留置カテーテル法の

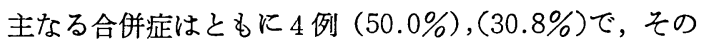
内容は膀胱瘦造設術では会陰部膿瘍, その他が 1 例( 25.0 $\%$ ，尿路（膀脱）結石 2 例（50.0\%）となつている。一 方, 留置カテーテル法では尿性器炎 2 例 $(50.0 \%)$, その 他が 2 例 (50.0\%) であつた。

治療成績からは，第1群では留置カテーテル法による 尿失禁を 1 例に認め, 第 2 群 下゙は膀胱瘦造設術に会陰部 膿瘍 1 例，尿路（膀脱）結石 2 例，留置カテーテル法で はその他を 1 例認めた．次に第 3 群においては，両者に その他をそれぞれ 1 例認めた。

e. 後遺症

膀脱瘦造設術 9 例中，後遺症は 7 例 $(77.8 \%)$ で，そ の内容は症痕性狭窟 5 例 $(55.6 \%)$, 尿失禁 1 例 (11.1 $\%)$,神経因性膀脂 1 例（11.1\%）であつた。一方, 留置 カテーテル法では 14 例中 7 例 $(50.0 \%$ ） 飞後遺症を認 めた。すなわち瘢痕性狭窄 6 例 $(42.9 \%)$ ，尿失禁 1 例 ( $7.1 \%)$ となつている.

両者に却ける後遗症は膀胱㾯造設術に多いことがわか つた。また両者に共通した主なる後遺症は痒痕性狭窄 でわずかではあるが尿失禁も存在する。

次に両者を治療成績から比較すると, 膀胱瘦造設術の 第 1 群は 9 例中 2 例 $(22.2 \%)$ で，いずれも後遺症を認 めない. 第 2 群は 3 例 $(33.3 \%)$ で全て疲痕性狭窄を後 遺症としている。第 3 群は疲痕性狭窄 2 例 $(22.2 \%)$,尿 失禁，神経因性膀脂々れぞれ 1 例 $(11.1 \%)$ ，計 4 例(44.4 \%）の後遺症を認めた.

これに対して留置カテーテル法では, 第1 群は14例中 1 例 $(7.1 \%)$ の尿失禁を，第 2 群では 4 例 $(28.6 \%)$ の洀痕性狭窄を，第 3 群では 2 例 $(14.3 \%)$ の洀痕性狭 窄を後遺症としている．両者とも第 2 ・第 3 群に执いて は全例に後遺症を認める。

\section{小 括}

第 1 表のごとく，全国38大学関係病院から寄せられた アンケートに対する解答より，本症は総計 150例で，尿 性器に打ける外傷の $22 \%$ 占めている。

地域別には，中部地区が最も多く，1機関当り 5.5 例 となつている.

性別で，男子が圧渞的に多く 146 例 $(97 \%)$,年令別
では21〜40才が約半数の81例（54\%）であつた。

受傷原因としては，交通事故が95例（63\%）と最も多 く，膀胱破裂を合併したものが23例（25\%）認められ た。

尿道損傷の程度（型）は，全層完全破裂45例（31\%）， 全層不完全破裂54例 $(37 \%)$,部分的破裂33例 (23\%), 間 質性破裂 2 例（1\%）となつている.

骨盤骨折部位では，恥骨骨折が最も多く123例，次い で坐骨，腸骨の順となつている。

泌尿器科受診までの時間から新鮮例之陳旧例に分類し 比較検討した.すなわち受傷後24時間以内に受診したも のを新鮮例と仮定した。

新鮮例は55例 $(37 \%)$,陳旧例は95例（63\%）であつ た。新鮮例に甜许る主訴は，尿道出血（肉眼的血尿）と 尿閉が最も多くそれぞれ26例 (47\%),計52例 $(94 \%)$ で あり，陳旧例のそれは排尿困難 48 例 $(50 \%)$, 层閉 23 例(25 $\%)$,血尿10例（11\%）が主なるものであつた．次に，新 鮮例の70\%が初回処置として 何らかの外科的治療を受 けているが，その内容は pull-through 手術と端々吻合 術がそれぞれ38\%と同率に行われ，次いで膀胱癭造設術 が24\%に認められた。一方, 陳旧例においては, 外科的 処置は $51 \%$ に施行され，新鮮例と同様 pull-through 手 術と端々吻合術はやはり同率で，それぞれ35\%となつて いる。また膀脂癭造設術は30\%であつた。 3 カ月以内の 治癒率は新鮮例で $55 \%$ ，陳旧例では45\%であつた。後遺 症についてみるに，新鮮例では $43 \%$ に，陳旧例では $67 \%$ に認められ，いずれも廐痕性狭窄が最も多く，特に新鮮 例では陰萎がかなりあつた（18\%)。

な捛，アンケートより受傷直後の新鮮例に対する治療 方法やその予後の実情を知ることにより本症に対する standard procedure がある程度確立できるのではなか ろらかと考兵，前述したごとき種々なる検討を試及た。 一方, 陳旧例については, 尿道狭窄に対する治療が主体 となつているので，ここでは省略させていただいた．

すなわち，新鮮例55例中，女子 2 例を除外した，男子 53例の治療成績より 4 種類の予後判定基準を設け，各種 の要因について，それぞれの治療法とを比較検討した。 その結果, 受傷後早期に打ける外科的処置では, 膀胱瘦 造設術よりも一次的尿道形成術の方が良い成績を怙さめ ていることが判明した。

な执，一次的尿道形成術中 pull-through 手術と端々 吻合術とを比較すると，第 $5 ， 8$ 表のごとく両者それぞ 
れ14例に施され，複雑骨折例や全層完全破裂例に対する 治療成績は端々吻合術の方がはるかにすぐれている．治 瘾所要期間については, pull-through 手術の方が短期 間に完治する傾向がうかがわれた，次に後遺症は pull一 through手術の方に圧倒的に多く，端々吻合術の約 2 倍 に相当し, 特に洀痕性狭窄と陰萎が多い。これに対して 尿失禁は端々吻合術のみに認める. かくのごとく全般的 には端々吻合術の方がすぐれているといえよう。

消極的処置としての膀胱㿉造設術と留置カテーテル法 との比較は第 5,9 表のごとく, 前者 9 例, 後者 14 例と なつているが, 単純骨折例には留置カテーテル法が多く 施行され，治癒率もすぐれている。しかし複雑骨折に括 いては両者の間に著明な差を認めなかつた，尿道損傷の 程度から比較すると, 留置カテーテル法は程度の軽い部 分的破裂や全層不完全破裂に多用され，治療成績も膀胱 瘦造設術に比しすぐれている．全層完全破裂に対しては 膀胱㾇造設術のみが行われているが，その治療成績はき わめて悪い．また治癒所要期間も留置カテーテル法がす ぐれている. 後遺症についても, 膀胱㿉造設術は 9 例中 7 例 $(77.8 \%)$ 諗められ, その主なるものは症痕性狭窄 であつた。一方, 留置カテーテル法は14例中 7 例 $(50.0$ \%)で，やはり痗痕性狭窄が多い.

また, 留置カテーテル法と一次的尿道形成術とを比較 すると，両者ともほとんど似かよつた治療成績をあげて いることから，損傷の程度を十分考慮した上での最初の 治療方針がきわめて適切であつたことを意味するものと 思われる。

治療成績と各種の要因についてみるに（第 6 表参照), 骨盤骨折では複雑骨折例よりも単純骨折例の方が治療
成績は良く，尿道損傷の程度（型）からの比較では，完 治例においては核とんど差を認めないが，後遺症を残す 症例では損傷の程度が大なるほど，すなわち，全層完全 破裂例ほど，治療成績は劣る。治癒所要期間について は，1 3 月月以内治瘦率は29例 $(54.8 \%)$ で, 当然 のことではあるが, 完治例程治癒所要期間 の短縮が み られる．合併症は，死亡例を除く男子50例中16例（32.0 \%) に認められ，特に完治例では尿性器炎が多い。 た, 膀胱結石はいずれも膀胱瘦造設術に認められた. 後遺症は死亡 3 例を除く, 男子 50 例中重複例を含め 34 例 (68\%) にみられた。 その主なるものは，疲痕性狭窄21 例 $(42.0 \%)$, 陰萎 6 例 $(12.0 \%)$, 尿失禁 4 例 $(8.0 \%)$, 瘦孔形成 2 例 $(4.0 \%)$, 神経因性膀脂 1 例 $(2.0 \%)$ と なつている。

上記のごとく，各術式や要因について比較倹討をすす めて来たが, 要するに早期に怙ける確実なる診断と適切 なる処置がきわめて重要であることを強調したい，特に アンケートよりの資料では尿道損傷の軽い場合には留置 カテーテル法が最もすぐれ，全層完全破裂のごとき重い 場合には消極的な処置よりも躊躇せず尿道端々吻合術を 行うべきである.

\section{II. 自験例}

名古屋市立大学医学部附属病院泌尿器科外来に打ける 過去15年間（1953年 1 月より1967年 9 月10日現在まで） の統計によれば，第10表のごとく，外来患者数は1960年 より年々増加の傾向を示し，本年（1957年）は新病院の 開設に伴い急激に増加している. しかし泌尿器外傷は, 第10表拉よび第13図に示すごとく, 外来患者数の増加に もかかわらずそれほど著変を示さない，すなわち，過去

第10表 泌尿器外傷の年度別推移 (名市大泌尿器科外来)

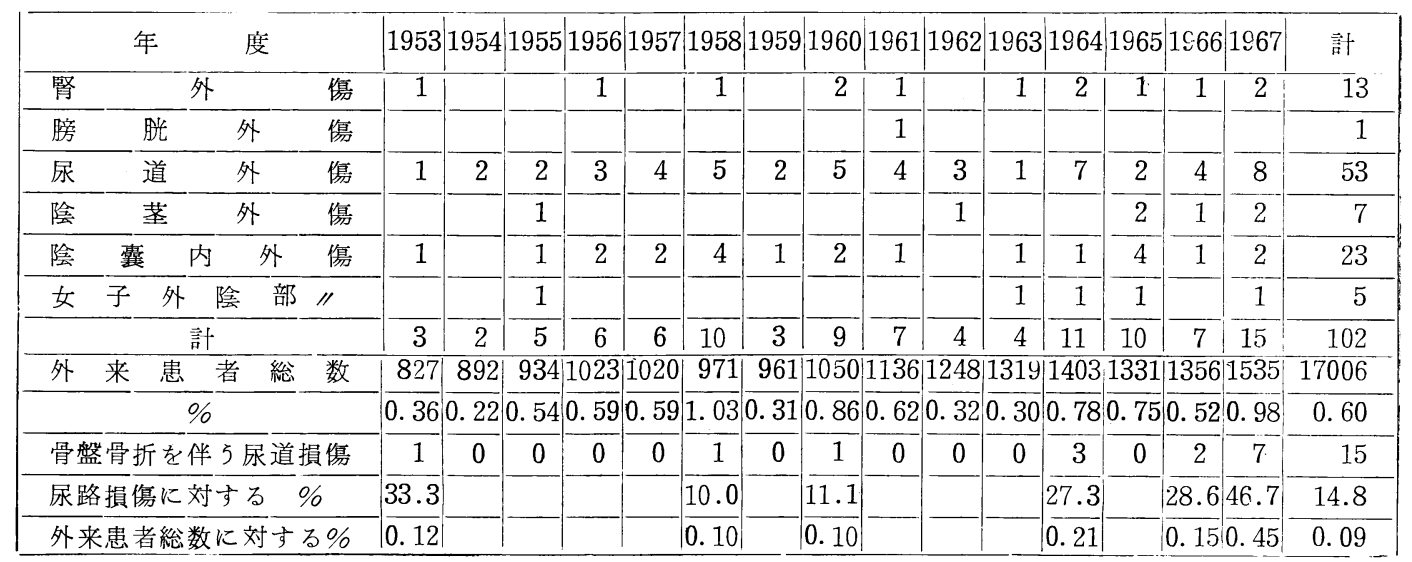


第13図 泌尿器外傷. 尿道損傷の年度別推移（名市 大, 東大）

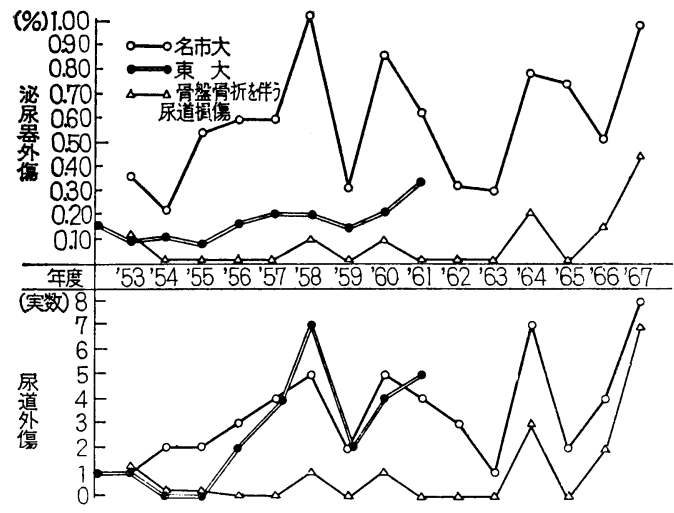

15年間の外来患者総数は17,006例で，尿性器外傷は 102 例 $(0.6 \%)$ であり，そのうち尿道損傷が約半数の53例 (52\%) を占めている. 次いで陰囊内，陰茎等の性器外 傷，腎外傷の順で，性別では圧倒的に男子が多い(95.1 \%).また骨盤損傷を伴ら後部尿道損傷は15例で，尿道損 摥に対する百分率は $28 \%$, 尿性器外傷に対するそれは $14.8 \%$, 外来患者総数に対してはわずか $0.09 \%$ に過ざな W.

当教室に叔ける本症15例の詳細は第11表のごとく，新 鮮例 7 例 $(47 \%)$, 陳旧例 8 例 (53\%) であり, 全国大学 院属病院からの集計結果（新蟹例37\%),陳旧例63\%) と ほぶ似かよつた傾向がみられる。

年令・性別. 12才以下は 1 例もなく，13〜20才 4 例 $(26.7 \%), 21 \sim 30$ 才 1 例 $(6.7 \%), 31 \sim 40$ 才 2 例 $(13.3$ $\%), 41 \sim 50$ 才 4 例 $(26.7 \%), 51 \sim 60$ 才 1 例 ( $6.7 \%), 60$ 才以上 3 例 $(20.0 \%)$ となつている.

性別ではやはり压倒的に男子が多く15例中14例（93.3 \%) を占めている。

受傷原因：15例中13例（86.7\%）が交通事故によるも のであつた。

泌尿器科受診までの時間：24時問以内に受診したもの 7 例 $(47 \%)$,24時間以上 8 例 $(53 \%)$ となつている.

主訴: 新鮮例では尿道出血（肉眼的血尿）が 3 例（43 $\%)$, 尿閉 3 例 $(43 \%)$, 排尿困難 1 例 $(14 \%)$,陳旧例では 排尿困難 5 例 $(63 \%)$, 尿閉，血尿および尿失禁それぞれ

1 例 $(12 \%)$ となつている.

尿道損傷の程度（型）: 尿道損傷の程度は, 間質性破 裂 4 例 $(26.7 \%)$, 部分的破裂 3 例 $(20.0 \%)$,全層不完全 破裂，完全破裂ともに 4 例 $(26.7 \%)$ であいた.
骨折部位：恥骨骨折が圧倒的に多く 12 例 $(80.0 \%)$,腸 骨骨折 6 例 $(40.0 \%)$,坐骨骨折 1 例 ( $6.7 \%)$ となつて いるが，重複例も含んでいる。

治療方法：新鮮例では 7 例中 4 例 $(57 \%)$ が膀胱瘻造 設術と留置カテーテルの併用をらけ, pull-through 手 術, 端々吻合術および留置カテーテル法のみの処置はい ずれも 1 例 $(14 \%)$ ずつとなつている. 手術施行 6 例に おける術施行までの時間的経過は, 受傷直後が 5 例， 1 例は 9 日目であつた. 術後のカテーテル留置期間は最短 12 日, 最長 3 力月, 平均 1 カ月となつている.

次に, 陳旧例については 8 例中, 尿道拡張術 5 例 $(62$ $\%)$, 端々吻合術, 留置カテーテル拈よび全身切開術打の 沶の 1 例 $(14 \%)$ であつた.

すなわち，陳旧例に拉ける症例 4 は某医にて受傷直 後, 膀胱瘦造設術と留置カテーテル法を受けたが, いず れの処置も不適当で高度の尿浸潤を来たし，受傷10日後 当科に送られて来たものである. 受診当時すでに全身皮 下に高度の尿浸潤を認め, $\mathbf{X}$ 線検査で後部尿道の全層完 全破裂と膀脱および直腸破裂を確認した。しかし尿毒症 のため全身状態悪く, 緊急的に切開排尿術を施したが， 術後 3 日目鬼籍に入つた.

また, 症例 6 は13才の女子であるが, 受傷直後某医に て治療を受けたが, その後, 後遺症として尿失禁が続 さ, 受傷 4 年後当科に迴わされた. 精査の結果, 膀脱尿 道腟瘦, 膀胱結石と診断, 直ちに瘦孔閉鎖術を試みたが 不成功に就わり，止むなく留置カテーテルを施したが， 術後 3 日目に麻痺性イレウスで死亡した。

これら 2 症例は, いずれも初回の診断と処置が不適当 であつたため重篤なる後遺症を併発したものと考劣る.

後遺症：新鮮例に拈いては予後不明の 1 例を除くと半 数の 3 例に大腿部膿瘍, 尿瘦形成, 瘢痕性狭窄の後遺症 を認めた. 陳旧例に拈いては死亡 2 例, 予後不明 1 例, 計 3 例を除く 5 例中 2 例 $(40 \%)$ に痗痕性狭窄学認め た。

\section{小 括}

過去15年間の当教室に括ける本症は総計15例で，尿性 器外傷に対する頻度は $14.8 \%$, 外来患者総数に対しては 0.09\%であつた。

性別では, 男子が圧倒的に多く93.3\%を占め, 年令別 では，20才以下と41〜50才がそれぞれ 4 例 (26.7\%), 次 いで60才以上が3 例 (20.0\%) で，アンケートに対する 解答とは異り，21〜40才の頻度は3 例 (20.0\%) に過ぎ なかつた．受傷原因は， $86.6 \%$ が交通事故によるもの 


$$
\begin{gathered}
\text { 第11表 自 験 例 } \\
\text { 新 鮮 例 }
\end{gathered}
$$

\begin{tabular}{|c|c|c|c|c|c|c|c|c|c|c|c|c|}
\hline 症例 & 作 名 & 年令 & 性 & 主＼cjkstart訴 & 受診迄の時間 & 骨折部 & $\begin{array}{l}\text { 尿道損 } \\
\text { 傷部位 }\end{array}$ & 分類 & 手治療方法 & 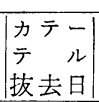 & 後遗症 & $\begin{array}{l}\text { 治療 } \\
\text { 期間 } \\
\end{array}$ \\
\hline 1 & 加 $\bigcirc$ & 16 & $\hat{\delta}$ & 血 & $\begin{array}{l}\text { 交通事故 } \\
\text { 後 }\end{array}$ & 䎵 骨 & 膜樣部 & 不完全 & 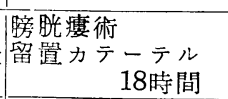 & 3カ月 & $\begin{array}{l}\text { 右大腿 } \\
\text { 膿 瘍 }\end{array}$ & 4 力月 \\
\hline 2 & 仙 $\bigcirc$ & 61 & $\hat{\sigma}$ & 尿 & $\begin{array}{l}\text { 交通事故 } \\
\text { 直 } \\
\text { 後 }\end{array}$ & 恥 骨 & 膜様部 & 部分的 & $\begin{array}{r}\text { 膀胱瘦術 } \\
\text { 置カデテル } \\
9 \text { 日目 }\end{array}$ & 42 日 & |尿瘦形成 & 3力月 \\
\hline 3 & 若○ & 21 & $\hat{\delta}$ & 排尿困難 & $\begin{array}{l}\text { 交通事故 } \\
\text { 直 }\end{array}$ & 恥 骨 & 膜様部 & 不完全 & $\begin{array}{r}\text { 留置カテーテル } \\
10 \text { 日目 }\end{array}$ & 12日 & ナシ & 3力月 \\
\hline 4 & 安○ & 61 & $\delta$ & 尿道出血 & $\begin{array}{l}\text { 交通事故 } \\
\text { 直 }\end{array}$ & 恥 骨 & 膜様部 & 完 & 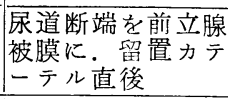 & \multicolumn{3}{|c|}{ 12日目転医以後不明 } \\
\hline 5 & $f_{12}$ & 31 & $\hat{0}$ & 尿道出血 & $\begin{array}{l}\text { 交通事故 } \\
\text { 直 後 }\end{array}$ & $\mid$\begin{tabular}{|l|l} 
両腸骨 \\
䐕
\end{tabular} & 膜様部 & 完 全 & $\begin{array}{l}\text { Pull-through } \\
\text { 直後 }\end{array}$ & 38日 & ナシ & 95日 \\
\hline 6 & 大O & 39 & $\hat{o}$ & 尿 & $\begin{array}{l}\text { 交通事後 } \\
\text { 直 後 }\end{array}$ & \begin{tabular}{|ll} 
腸 & 骨 \\
恥 & 骨 \\
\end{tabular} & 膜様部 & 不完全 & $\begin{array}{r}\text { 影腷瘦術 } \\
\text { 置カテーテル } \\
\text { 直後 }\end{array}$ & 48日 & ナシ & 1 年 \\
\hline 7 & 山O & 41 & $\hat{0}$ & \begin{tabular}{|lr} 
尿 & 閉 \\
尿道出血
\end{tabular} & $\begin{array}{l}\text { 交通事故 } \\
\text { 直 }\end{array}$ & 恥 骨 & 球 部 & 間質性 & $\begin{array}{r}\text { 膀胱瘻術 } \\
\text { 置カテーテル } \\
\end{array}$ & 27日 & $\left|\begin{array}{|}\text { 尿道狭窑 } \\
\text { ルブジー } \\
\text { ルング }\end{array}\right|$ & 30 日 \\
\hline
\end{tabular}

\begin{tabular}{|c|c|c|c|c|c|c|c|c|c|c|c|c|}
\hline 症例 & 氏 名 & 年令 & 性 & 主＼cjkstart訴 & 受訅迄の時間 & 骨折部 & $\begin{array}{l}\text { 层道損 } \\
\text { 傷部位 }\end{array}$ & 分類 & $\begin{array}{l}\text { 手街选方法 } \\
\text { 時間 }\end{array}$ & $\left|\begin{array}{ll}\text { カ } & \\
\text { テ } & ル \\
\text { 抜去日 }\end{array}\right|$ & 後遺症 & $\begin{array}{l}\text { 治療 } \\
\text { 期間 }\end{array}$ \\
\hline 1 & 佐 $\bigcirc$ & 61 & $\hat{0}$ & 排尿困難 & $\begin{array}{l}\text { 交通事故 } \\
5 \text { 力後 }\end{array}$ & 恥骨 & 膜梯 部 & 部分的 & $\begin{array}{l}\text { ブジールソグ } \\
(\text { No. 20) }\end{array}$ & & & 4力月 \\
\hline 2 & 安 & 57 & $\hat{0}$ & 排尿困難 & $\begin{array}{l}\text { 交通事故 } \\
11 \text { 月後 }\end{array}$ & 腸 骨 & 膜様部 & 間質性 & $\begin{array}{l}\text { ブジールング } \\
(\text { No. 23) }\end{array}$ & \multicolumn{3}{|c|}{ 労㷋病院へ転医 } \\
\hline 3 & 中० & 43 & $\hat{\delta}$ & 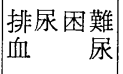 & $\begin{array}{l}\text { 交通事故 } \\
10 \text { 日後 }\end{array}$ & 䎵 骨 & 膜様部 & 間質性 & $\left\{\begin{array}{l}\text { ブ ジールング } \\
(\text { No. 24) }\end{array}\right.$ & & & 3 力月 \\
\hline 4 & 石 & 42 & $\hat{\delta}$ & 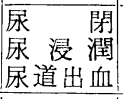 & $\begin{array}{l}\text { 交通事故 } \\
10 \text { 後 }\end{array}$ & 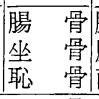 & 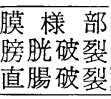 & 完 全 & \begin{tabular}{|l|} 
全身皮下・尿浸潤 \\
開排液
\end{tabular} & \multicolumn{3}{|c|}{ 3日目死亡 } \\
\hline 5 & 神 $\bigcirc$ & 20 & $\hat{\delta}$ & $\left|\begin{array}{rl}\text { 排尿困難 } \\
\text { 漊 }\end{array}\right|$ & $\begin{array}{l}\text { 交通事故 } \\
5 \text { 力月後 }\end{array}$ & $\mid$\begin{tabular}{|l} 
坐 \\
骨大腿 \\
左下腿
\end{tabular} & 膜様部 & 不完全 & $\left|\begin{array}{|c|}\mid \\
\text { 端々吻合術 } \\
\text { 受甥 } 5 \text { カ月後 }\end{array}\right|$ & 15日 & (狭 窄 & 39日 \\
\hline 6 & 山○ & 13 & 우 & 尿失禁 & $\begin{array}{l}\text { 腰部圧迫 } \\
2 \text { 年 } 6 \text { 力後 }\end{array}$ & \begin{tabular}{|ll} 
腸 & 骨 \\
恥 & 骨
\end{tabular} & $\begin{array}{l}\text { 层道・腟 } \\
\text { 結 石) }\end{array}$ & 部分的 & 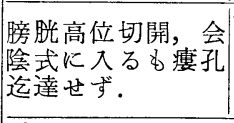 & \multicolumn{3}{|c|}{ 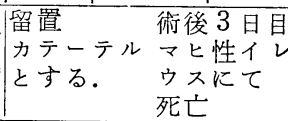 } \\
\hline 7 & 渡○ & 19 & $\hat{0}$ & 血 尿 & $\begin{array}{l}\text { 䎐 } \\
2 \text { 力月落 } \\
2 \text { 後 }\end{array}$ & 左腸骨 & 前立腺 部 & 間質性 & 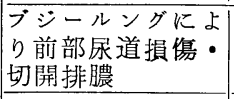 & \multicolumn{3}{|c|}{ 治 療 中 } \\
\hline 8 & * $\bigcirc$ & 44 & $\hat{o}$ & 排尿困難 & \begin{tabular}{|c|} 
交通事故 \\
4 年 後 \\
(尿道形成術) \\
\end{tabular} & 䎵 骨 & 膜様部 & & ブジールング & \multicolumn{3}{|c|}{ 治 療 中 } \\
\hline
\end{tabular}

陳旧例 
で，膀脱破裂の合併は $13.3 \%$ となつている，尿道損傷の 程度は，間質性破裂，全層不完全破裂特よび 全層完全 破裂がそれぞれ 4 例 (26.7\%),部分的破裂が 3 例（20.0 \%)であつた。骨盤骨折部位ではやはり恥骨骨折が最も 多く12例で, 次いで腸骨, 坐骨の順となつている. 泌尿 器科受診までの時間は, 受傷後24時間以内に受診したも のが 7 例 $(47 \%)=$ 新鮮例 $=, 24$ 時間以上のものが 8 例 (53\%) =陳旧例=であつた．これはアンケートの解答 結果と似かよつた数値を示した。

また新鮮例における主訴は，尿道出血および尿閉がお の怙の 3 例 $(43 \%)$,陳旧例では排尿困離が多く，8例中 5 例 $(63 \%)$ を占めている.

新鮮例の $86 \%$ が初回処置として何らかの外科的処置を 受けているが, 当教室では膀胱癭造設術が最も多く, 7 例中 4 例 $(57 \%)$ となつている.Pull-through手術と端 々吻合術はそれぞれ1例（14\%）であつた。なお，膀胱 㾇造設術 4 例中 3 例（75\%）飞後遺症を認めた.

一方，陳旧例に扣いては尿道拡張術が 5 例 $(62 \%)$ と 最も多く, 端々吻合術, 留置カテーテルおよび切開排尿 術おのおの 1 例で，2 例の死亡例をみている.

後遺症は，新鮮例では $50 \%$ ，陳旧例では $20 \%$ に認めら れた。

以上，当教室に打ける自験例について述べたが，いず れも例数が小いため, 到底, 治療成績から治療法を比較 できない，今後はアンケートより得られた結果を参考と して，本症の治療垱つて行きたい，

\section{III. 整形外科領域からの観察}

年々激增する交通事故の骨折患者に対する尿道損傷の 頻度や，骨盤骨折を伴ら尿道損傷患者飞対する整形外科 医の治療方針の実態を探る目的で，整形外科領域からの 統計的観察を試みた。

名古屋市立大学医学部附属病院整形外科教室ならびに 該教室関連 7 病院に拈ける交通事故による骨折患者の過 去 3 年間（1963～1965年）の年度別推移は，第12表，第 14図に示すごとく，骨折患者が年々増加するにつれ，骨 盤骨折を伴う尿道損傷も増加している.

すなわち，骨折患者総数 729 例中，骨盤骨折は 56 例 ( $7.7 \%)$ ，骨盤骨折を伴う尿道損傷は15例 $(2.1 \%)$ で ある。また骨盤骨折56例に対する尿道損傷は15例 (26.8 \%)となり，交通事故による骨盤骨折患者の約 $1 / 3$ に尿道 損傷を伴つていることがわかつた。

性別については，骨折患者総数 729例中，男子 578例 $(79.2 \%)$,女子 151 例 $(20.8 \%)$ で，本症の男女比は 15
第12表 交通事故に上る骨折患者の年度別推移 名市大, 東市民, 名鉄, 小牧, 大垣市民, 愛北, 山 下病院 7機関，整形外科集計資料

\begin{tabular}{|c|c|c|c|c|}
\hline 年 & 1963 & 1964 & 1965 & 計 \\
\hline 骨折 患者総 数 & 184 & 252 & 293 & 729 例 \\
\hline 骨 盤 骨 折 & 9 & 14 & 33 & 56 \\
\hline $\begin{array}{l}\text { 骨盤骨折を伴 5尿 } \\
\text { 道損傷 }\end{array}$ & 2 & 5 & 8 & 15 \\
\hline $\begin{array}{l}\text { 骨折患者に対する } \\
\text { 骨盤骨折 } \\
\end{array}$ & 4. 89 & 5.56 & 11.26 & $7.68 \%$ \\
\hline $\begin{array}{l}\text { 骨折患者に対する } \\
\text { 骨盤骨折を伴 } 5 \text { 尿 } \\
\text { 道損傷 }\end{array}$ & 1.09 & 1.98 & 2.73 & 2.06 \\
\hline $\begin{array}{l}\text { 骨盤骨折に対する } \\
\text { 算損伹 }\end{array}$ & 22.22 & 35.71 & 24.24 & 26. 79 \\
\hline
\end{tabular}

第14図。骨盤骨折を伴 万尿道損傷と交通事故

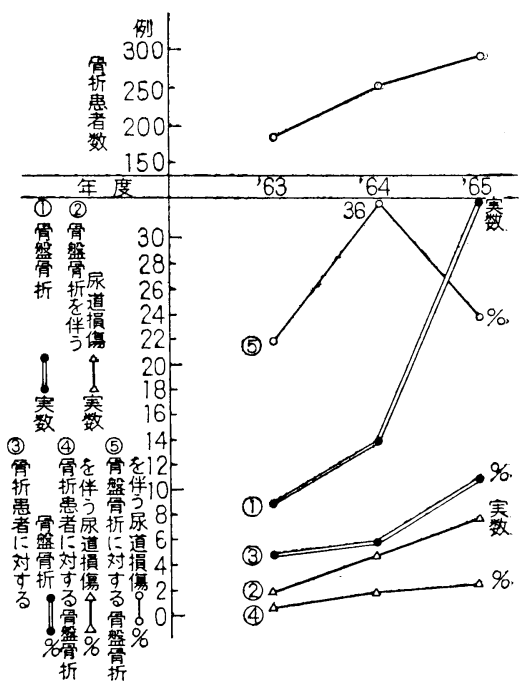

例中, 男子14例 $(93.3 \%)$,女子1例（6.7\%）となり， 圧倒的に男子に多い（第13表参照）.

次に，本症15例中名市大整形外科で取扱つた症例は 5 例で，いずれも当教室（泌尿器科）を受診している。そ のらち 3 例は部分的尿道破裂と診断, 留置カテーテル法 を施行, 整形外科病棟にて骨折に対する治療を受けさせ た. 残り 2 例は全層完全破裂の診断のもとに泌尿器科飞 入院, 直ちに一次的尿道形成術を施行, 同時飞整形外科 的に骨盤率引療法を受けた（自験新鮮例，症例 4 および 5 ).

なお，名市大整形外科以外の機関で処置された 10 例に ついては不明である。 
第13表 交通事故による骨折患者の年度別推移 (名市大整形外科)

\begin{tabular}{|c|c|c|c|c|c|c|c|c|c|}
\hline \multirow{2}{*}{ 年度 } & \multicolumn{2}{|c|}{$\begin{array}{l}\text { 骨 折 患 } \\
\text { 者 総 数 }\end{array}$} & \multicolumn{3}{|c|}{ 滑盤骨折 } & \multicolumn{3}{|c|}{\begin{tabular}{|l} 
骨盤骨折を伴 \\
5 尿道損傷 \\
\end{tabular}} & \multirow{2}{*}{$\%$} \\
\hline & 総数 & 性 別 & 総数 & 性 & 別 & 総数 & 性 & 別 & \\
\hline 1963 & 184 & $\begin{array}{l}\text { 男 } 152 \\
\text { 女 } 32\end{array}$ & 9 & $\begin{array}{l}\text { 男 } \\
\text { 女 }\end{array}$ & & 2 & $\begin{array}{l}\text { 男 } \\
\text { 女 }\end{array}$ & $\begin{array}{l}2 \\
0\end{array}$ & $\begin{array}{r}4.89 \\
1.09 \\
22.22\end{array}$ \\
\hline 1964 & 252 & $\begin{array}{l}\text { 男 } 204 \\
\text { 女 } 48\end{array}$ & 14 & & & 5 & $\begin{array}{l}\text { 男 } \\
\text { 女 }\end{array}$ & & $\begin{array}{r}5.56 \\
1.98 \\
35.71\end{array}$ \\
\hline 1965 & 293 & $\begin{array}{l}\text { 男 } 222 \\
\text { 女 } 71\end{array}$ & 33 & & & 8 & $\begin{array}{l}\text { 男 } \\
\text { 女 }\end{array}$ & $\begin{array}{l}7 \\
1\end{array}$ & $\begin{array}{r}11.26 \\
2.73 \\
24.24\end{array}$ \\
\hline 計 & 729 & $\begin{array}{l}\text { 男 } 578 \\
\text { 女 } 151 \\
\end{array}$ & 56 & & $\begin{array}{l}40 \\
16\end{array}$ & 15 & & & $\begin{array}{r}7.68 \\
2.06 \\
26.79\end{array}$ \\
\hline
\end{tabular}

\section{考案}

最近, 交通事故の激増に伴い各種の外傷性疾患が増加 こつつあるが，骨盤骨折を伴う尿道損傷も例外ではな く，著者の統計からも年々増加の傾向にある.

そこで本症の頻度, 治療方法括よび後遺症に重点をお き,アンケートよりの解答と自験例から考察する。

\section{I. 頻度}

泌尿器外傷の頻度は一般外傷に比べ比較的まれである といわれているが，黒川・大田黒 $(1964)^{14)}$ の 報告によ れば 0.5〜 2.0\%内外を占めるという.な拈, 泌尿器疾 患 (外来患者総数) に対する泌尿器外傷の頻度は, 東大 䟤尿器科教室における過去10年間の統計では0.17\%であ り，当教室に括汀るとれは $0.6 \%$ となつてる（第13図 参照).

また, 泌尿器外傷が骨盤骨折に伴つて 発生する頻度 はMcCague ら (1944) $)^{9}$ にると 780例中 133例 (17.0 \%）が尿道破裂をたは膀胱破裂を伴つたという，Campbell $(1963)^{2)}$ は 166例中膀脱破裂25例 (15\%) を認め たと述べ，Wilkinson $(1961)^{10)}$ は 1,400例 の骨盤骨折 中後部尿道破裂 $10 \%$, 膀胱破裂 $5 \%$, その両者の場合 は $1 \%$ であといい，志田 $(1954)^{15)}$ は尿道損傷 121例 中26例 $(21.4 \%)$ に骨盤骨折を認めたと述べている。 た黒川・大田黒 (1964) ${ }^{14)}$ は一般外傷 527例中13例( 2.4 \%）飞骨盤骨折を，そのらち膀胱破裂と尿道破裂がそれ ぞれ 2 例存在すると報告している. 塙ら $(1961)^{12)}$ は膀胱 破裂 $10.7 \%$ ，尿道断裂16.7\%であると述べている.

アンケートに対する解答よりの骨盤骨折を伴う後部尿 道損傷は総計 150 例で, “泌尿器外傷の $22 \%$ を占めてい る.また，当教室においては本症は15例で，泌尿器外傷
の $14.8 \%$ を示した. 本学整形外科学教室からの資料で は，本症は $2.1 \%$ であつた。

以上述べたごとく, 本症の頻度は泌尿器科の立場から 観察した場合と外科または整形外科的立場からの報告と は著しく異つている.われわれ泌尿器科からみると, 本 症は泌尿器外傷のらち10\%〜20\%の範囲内にあるものと 思われる。

\section{II . 受診までの時間}

アンケートによると, 受傷後24時間以内に泌尿器科を 受診せるものは55例（37\%）であつた。また自験例にお いても 7 例 $(47 \%)$ が受傷直後に受診している.これら の統計から,大部分はまず他科を受診し，そこでショック や骨折に対する処置を受け, 次いで尿道損傷に対する治 療が施されているのではなかららか，そして全身状態の 回復後あるいは骨折が治癒した時, 尿道損傷の後遺症と して排尿困難等の症状が持続する場合に，われわれ泌尿 器科医のところに送られてくるものと思われる。これは アンケートによる解答で，陳旧例が95例 $(63 \%)$ 存在す ることからも推測できる，それ故，いろいろな事故を扱 う救急指定病院や泌尿器科専門医のいない病院で, 本症 患者を取扱ら医師は尿道損傷に対するある程度の知識と 処置を行つていれば，より以上に複雑な損傷を惹起させ ずにすむものと思う．特に，自験陳旧例 4 のごときは， おざなりの尿道撮影を行つたために尿道損傷の程度も確 認せず，また最も重大な膀胱破裂を見逃し，乙かも尿閉 に対する不適当な処置を行つた故にきわめて高度の尿浸 潤と感染が起り，当科受診時には全く手の施しょうもな く不幸な転帰をとつた症例で，如何に早期の確実なる診 断と適切なる処置が重要であるかを改めて痛感した.

受傷後受診までの時間が大きく予後に影響することは アンケートの集計結果より明らかである。すなわち，受 傷後24時間以内に受診したもの（新鮮例）の後遺症は43 \%であるが，24時間以上を経て受診したもの（陳旧例） は67\%であつた。これはとりもな拈さず早期の診断と治 療が適切に行われることにもなる。

\section{III. 早期診断}

受傷後早期に括ける確定的な診断を下すように心がけ ねばならない。これは次に行らべき治療ひいては損傷治 癒にきわめて重要な因子となるからである。

確定診断を下すには，まず損傷状況を精査し，症状特 よび直腸診より損害部位を推測する，次いで必ず尿道撮 影を行らべきである．この尿道撮影像から損害の程度 （型）が正確に判定できることは，多くの著者が述べて 
いるところである．尿道撮影を行ら前に尿または注入夜 の排出状況を知る目的でやみくもにカテーテルの挿入を 行つてはならない.

これはいたずらに尿道損傷を複雑にし，特に未熟な技 術に括いては受傷以外の人工的な損傷を作るからであ る。

尿道撮影によつてカテーテルの膀胱内挿入が可能と判 断したならばすみやかにこれを挿入し，一旦挿入し得た ならば決して除去することなく 1 週間位はそのまま留置 すべきである．ここで注意すべきは全層破裂の場合で， この場合にはカテーテルが損傷部位から膀胱前腔等尿道 外飞挿入され，あたかも膀胱内に挿入されたように思わ れることである．この場合と膀胼破裂の鑑別が問題にな るが，確実な鑑別法は挿入されたネラトンに造影剤を注 入し膀胱造影像をみるべきである。

カテーテル插入不能の場合は無益な urological instrumentation を繰り返すことなく，すみやかに手術的に尿 路の再建をはかるべきである.

いずれにせよ，確定診断が得られたならば，一般状態 の許す限り直ちに手術を施行すべきであり, 保存的療法 を固執することは予後を悪化させるのみで好ましくな い.

\section{IV. 治療方法}

著者は，アンケートより受傷直後の 新鮮例につい て，それらの治療方法や予後の実情を知ることにより， 本症に対する standard procedure がある程度確立でき るのではなかろらかと考光，新鮮例における治療成績よ り予後に対する判定基準を設け，これを 4 群に分類し種 々比較検討した. その結果, 受傷後早期に括ける外科的 処置では, 膀脂㿉造設術よりも一次的尿道形成術の治療 成績がはるかにすぐれていることがわかつた。 しかも一 次的尿道形成術中, pull-through 手術と端々吻合術を 比較すると後者がすぐれている結果を示した.

また，膀胱瘦造設術と留置カテーテル法とを比較する と，尿道損傷の程度の軽い場合に多用されている面もあ るが, 留置カテーテル法がすぐれている．損傷程度の重 (場合（例えば全層完全破裂）には当然留置カテーテル の対象とはならないが, 膀胱瘦造設術を施行した場合そ の予後は悪い.この場合には一次的尿道形成術を積極的 に選ぶべさである。

この点に関して，Kusmierski ら (1965) 王は骨盤骨折 を伴う尿道損傷50例について種々観察している. 彼は, 本症の患者は通常重篤な外傷性ショックに宿入つてい るので，尿道損傷が軽度であるとそれに気付泇ずにい
る.しかし，広範なる骨盤骨折や会陰部の損傷が大きい 場合には, 周囲組織への尿拉よび血液浸潤が増加して二 次的ショックを惹起させるので, ショックに対する処置 を十分に行つた後, 少くとも受傷後 $24 \sim 48$ 時間を経て尿 道の修復を行わねばならないと述べ，自験50例中 21 例が 受傷後10時間以内に手術を受けたが，良好な結果を得た のはわずかに 1 例のみであつたと報告している。そこで 彼は受傷後, 直ちに手術をしなければならない時はでき るだけ小箱囲にとどめ，まず第 1 段階として膀胱㾇造設 術や会陰部の drainage を施行し, 次いで24〜48時間後: に尿道重積法を採用することをすすめている.

また，治療成績は直接的には骨盤骨折の程度に左右さ れ，尿道形成のために選ばれた手術術式には何ら差異を 認めなかつたとも述べている。

著者も, 手術施行時期に関してはこの意見に賛成であ, るが, アンケートの結果からみると手術術式によつてか. なりの差があるように思われる. 要は, 症例によつて損 傷の程度がそれぞれ異るので， case by case により治. 療方針や手術術式を選択せざるを得ないが，アンケート の集計結果はある程度参考になるのではなかろらか.

な招，堀内ら $(1965)^{13)}$ は尿道狭竹に打汁る手術術式: の選択方法について, 自験18例の尿道端々吻合術の遠隔: 成績を詳細に検討し，狭窄の長さが $2 \sim 3 \mathrm{~cm}$ の場合は端 々吻合術が最もすぐれ，㹨窄部位がさらに後部におよぶ 時には pull-through 手術, 狭窄が長く, 緊張なく尿道 縫合ができない時には Johanson’s 手術を行うのが良策 であると述べている，さらに新鮮例の場合にも言及し， 他に重篤な外傷があり生命を救らに尿道の手術を行な い得ない時はともかく，保存的に治癒しても結局狭窄 を来たすことが多いからできるだけ早く，狭窄の来ない らちに尿道端々吻合術を行らべきであると強調してい る.

これは著者が集計したアンケートからの結果と全く同 一の意見である，それ故に尿道全層破裂の場合はできる， だけ端々吻合術を採用することが望ましい。

V. 予後ならびに後遺症

予後に影響を与える重篤なる合併症は感染と尿浸潤で あるが，化学療法の発達している現在ではそれらによる 死亡率は非常に減少している. 加らるに早期の適確なる 診断と治療を施せばこれらの危惧は注とんどないと云 つてよい.ちなみに1934年に拈ける Hansen ${ }^{5)}$ の報告に よれば，尿道破裂 135例中死亡例は39例（29\%）である が，1946年の Howland ${ }^{6)}$ の報告では60例の尿浸潤中死： 
亡したのはわずか $6 \%$ あつった.アンケートからでは 150 例中 3 例 $(2 \%)$ 飞過ぎない.

しかしながら，外傷自体による生命の危険 は別問題 として，尿道損傷に怙ける予後はきわめて悪い，志田 $(1954)^{15}$ とよると，尿道破裂21例中臨床的に治瘉と認め られたものは12例（57\%）に過ぎず，残りの $43 \%$ に後遺 症を認めたという，後遺症として Hansen $(1934)^{5)}$ は尿 道破裂96例中, 尿道狭窄が25例 $(26 \%)$, 性欲の障害32例 $(34 \%)$, 尿失禁 7 例 $(7 \%)$, 瘦孔形成 6 例 $(6 \%)$, 尿道 䕀室形成 3 例 $(3 \%)$ で, 完全治癒はわずか 2 例（2 \%）に過ぎなかつたと述べている.

アンケートによると，骨盤骨折を伴う後部尿道損傷 150例中，後遺症は重複例を含め，98例 $(65.3 \%)$ に認 められ，尿道損傷における後遺症に関しては一と昔前と ほとんど変らない。

そこで, 男子新鮮例50例（死亡 3 例を除く）に和ける 後遺症を治療方法より検討してみると第14表に示すご とく, 重複例 4 例を含め34例 $(68.0 \%)$ 飞後遺症を認め る。その主なるものは洀痕性狭窄 21 例 $(42.0 \%)$, 陰萎 6 列 $(12.0 \%)$ 尿失禁 4 例 $(8.0 \%)$, 瘦孔形成 2 例 $(4.0$ $\%)$,神経因性膀脱 1 例（ $2.0 \%)$ である.

第 14 表 治療方法と後遗症

\begin{tabular}{|c|c|c|c|c|c|}
\hline \multirow[t]{2}{*}{ 症例数 } & \begin{tabular}{|l|} 
男子新 \\
鮮 例
\end{tabular} & $\begin{array}{l}\text { Pull- } \\
\text { through } \\
\text { 手術 }\end{array}$ & 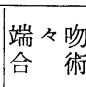 & 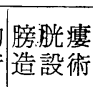 & $\mid \begin{array}{l}\text { 留置力 } \\
\text { 另-テ } \\
\text { L }\end{array}$ \\
\hline & 50 & 14 & 14 & 9 & 14 \\
\hline |実 数 & 30 & 10 & 6 & 7 & 7 \\
\hline 後寈症重複例 & 4 & 3 & 1 & & \\
\hline 般痕性狭 窄 & 21 & 7 & 3 & 5 & 6 \\
\hline 陰 & 6 & 5 & 1 & & \\
\hline 尿失 & 4 & & 2 & 1 & 1 \\
\hline 瘦 孔形 成 & 2 & 1 & 1 & & \\
\hline 神経因性膀胼 & 1 & & & 1 & \\
\hline
\end{tabular}

後遺症として最も多い症痕性原道狭窄は全ての治療法 こ認められる. 最も少い治療方法は端々吻合術の3 例 (21.4\%) であり, 最も多いのは pull-through 手術の 7 例 $(50.0 \%)$ であつた。

次に意外之多い後遺症は陰萎で, いずれも一次的尿道 俢成術にみられ，ことに pull-through 手術に圧倒的に 多い.すなわち陰萎 6 例中の 5 例 $(83.3 \%)$ を占めてい 5 .

尿失禁 4 例中端々吻合術に起因するのが半数の 2 例に 忍められる。
また，瘦孔形成の 2 例はいずれも一次的尿道形成術に 認める.

1 例の神経因性膀胱は膀胱㾇造設術にみられた。

かくのごとく，尿道形成術を後遺症の面から比較検討 すると, やつかいな症痕性狭窄や陰萎に関しては pullthrough 手術よりも端々吻合術の方がはるかにすぐれて いる. 後遺症としての陰菱がいずれも尿道形成術にのみ 認められるが，これは必ずしも手術術式によるものとは 断言できない，何故ならば尿道形成術を行らよらな症例 は当然尿道損傷の程度が大きい場合であり，このような 症例では局所における障害も高度で陰茎海綿体を支配し ている神経や血管, あるいは triangular ligament が著 しく障害されているるのと思われる。このような分野に さらに広範囲な手術侵襲を加えることによりますます局 所組織の障害が起り, 結果として陰萎が惹起されるので はなかろらか.この場合には, pull-through 手術よりも 端々吻合術の方が局所に対する負担が少いので良い成績 をあげうるものと考える.

尿道形成術後の陰萎は, Young (1929) ${ }^{11)}$ によると血 管障害に起因するといい, Abbott (1921) 1) は cavernous nerves の障害によつて起ると述べている. 一方, Wilkinson $(1961)^{10)}$ は彼の自験例において, 前立腺や膀胱あ るいは膀胱頝部を支配している神経が障害されたという 証拠がないため, 多分, 血管障害により陰萎が発生する のではなかららかと述べている.

ちなみに，外国文献によるとHartmann (1955) 4) は骨 盤骨折を伴つた尿道損傷の $40 \%$ が陰萎になつたと述べ， Wilkinson (1961) ${ }^{10)}$ は骨盤骨折を伴つた尿道破裂12例 中 3 例 $(25 \%)$ に陰萎を認め,さらにChambers ら $(1963)^{3)}$ は骨盤骨折を伴う 尿路外傷31例中尿道損傷は 15例で，その全例に陰萎を認めている. すなわち15例中 7 例 $(22 \%)$ が一時的な陰萎を，8例 $(26 \%)$ が永久的 な陰菱を残したと報告している.

また, 堀内ら $(1965)^{13)}$ は17例の尿道端々吻合術施行 例を長期間追跡した結果，本手術に起因した陰萎はわず か 1 例であつたといい, 内外文献から尿道端々吻合術の まとまつた遠隔成績は Maurer (1950) ${ }^{8)}$ の報告のみで， 他には全くみあたらないと述べている。

以上, アンケートよりの解答を主体として, “骨盤骨 折を伴う後部尿道損傷”を治療方法拈よび治療成績の面 から観察し若干の考察を行つた.

\section{結 語}

1. 骨盤骨折を伴ら後部尿道損傷について, 全国36大 
学附属病院ならびにその 2 分院, 計38機関からのアンヶ 一トを対象として統計的観察を行つた.

1）男子 146例, 女子 4 例, 計 150 例を数えた. 新鮮例は55例, 陳旧例は95例であつた。

2）受傷原因は，交通事故が最も多く95例であつた.

3）尿道損傷の程度は，間質性破裂 2 例，部分的破裂 33 例, 全層不完全破裂54例, 全層完全破裂45例であつ た。

4）骨盤骨折部位は，重複骨折例を含めると恥骨骨折 123例, 坐骨骨折38例, 腸骨骨折20例であつた.

5）新鮮例に対する治療方法は，尿道端々吻合術， pull-through 手術打よび留置カテーテル法がそれぞれ 14例, 膀胱瘦造設術 9 例, 安静療法, 不明が括の括の 1 例，女子 2 例であつた。

6）尿道形成術に和ける治療成績は，端々吻合術が pull-through 手術よりすぐれていた.

7）新鮮例に劣ける後遺症は, 瘵痕性狭窄 21 例, 陰萎 6 例, 尿失禁 4 例, 瘦孔形成 2 例, 神経因性膀胱 1 例, 計34例であつた.

2. 当教室に括ける過去15年間の本症に対する統計的 観察を試み，主なる症例について報告した。

1）自験例は男子14例, 女子 1 例, 計15例であつた. らち新鮮例は 7 例, 陳旧例は 8 例であつた.

2）受傷原因は，交通事故が多く13例であつた，

3）尿道損傷の程度は，間質性破裂，全層不完全破裂 裂，全層完全破裂それぞれ 4 例，部分的破裂 3 例であつ た。

4）骨盤骨折部位は, 重複例を含め, 恥骨骨折12例, 腸骨骨折 6 例, 坐骨骨折 1 例であつた.

5）新鮮例に対する治療方法は，7 例中 4 例が膀胖瘦 造設術で, 端々吻合術, pull-through手術および留置カ テーテル法はそれぞれ1例であつた。

6）新鮮例に打ける後遺症は，瘢痕性狭窄，大腿膿瘍 および尿瘦形成がおのおの 1 例であつた。

7）自験15例中死亡例は 2 例で，いずれも陳旧例にみ られ，特に 1 例はきわめて高度の尿浸潤を併発してい た.
3. 本学整形学数室に打ける, 交通事政による骨折患 者は過去 3 年間で 729 例を数え, そのうち骨盤骨折を伴 う尿道損傷は15例であつた。

4. 以上より，早期に和ける確実なる診断と適切なる 処置が本症の予後を左右するきわめて重要な因子である ことを確認した．特にアンケートの解答を集計した結 果, 尿道損傷の軽い場合には留置カテーテル法がすぐ れ，全層破裂のごとき重い症例には尿道端々吻合術が最 もすぐれた治療法であることを知つた.

稿を終るに臨み，御校閲を賜つた恩師岡直友教授に深 く感謝致します。さらに貴重なる資料を提供された各大 学泌尿器科学教室ならびに本学整形外科学教室に深甚な る謝意を表します。

な打本論文の要旨は日本泌尿器科学会第18回中部連合 地方会のシンポジゥムで報告した.

\section{文献}

1) Abbott, A.C.: Canad. Med. Ass. J., 20, 634, 1929.

2) Campbell, M.: Urology, Philadelphia, W.B. Saunders Co., 940, 1963.

3) Chambers, H.L. \& Balfour, J.: J. Urol., 89, $702,1963$.

4) Hartmann, K.: Arch. klin. Chir., 282, 943, 1955.

5) Hansen, J.: Erg. d. Chir. u. Orthop., 27, 407, 1934.

6) Howland, W.S.: J. Urol., 56, 387, 1946.

7) Kusmierski, S. \& Tobik, S.: J. Urol., 93,604, 1965.

8) Maurer, J.E.: J. Urol., 65, 895, 1951.

9) McCague, E.J. \& Semans, J.H.: J. Urol., 52, 36, 1944.

10) Wilkinson, F.O.W.: Lancet, 1, 1125, 1961.

11) Young, H.H.: J. Urol., 21, 417, 1929.

12）塙 良三, 栗原欣一，西蔭雄二 : 臨床皮泌， 15, $537,1963$.

13）堀内誠三, 富田義男, 横山正夫, 三谷玄悟: 手 術, 19, 643, 1965.

14）黑川一男, 大田黒和生 : 手術, 18, 36, 1964.

15) 志田圭三 : 泌尿器科新書 $(T-2)$, 南江堂, 東 京, 1954.

（昭和44年 1 月 8 日受付） 